\title{
Expresiones religiosas en las ciudades del poder de la Hispania Céltica: el caso de Clunia
}

Silvia Alfayé Villa

\section{Universidad de Zaragoza}

alfaye@unizar.es

Fecha recepción 22.02.2016 / Fecha aceptación 13.04.2016

\section{Resumen}

Este trabajo se centra en el estudio de las expresiones religiosas documentadas en la sede conventual de Clunia y, especialmente, en la «Cueva de Román», un santuario subterráneo vinculado a las reservas hídricas de la ciudad en el que se celebraron diversas prácticas cultuales con la participación, entre otros, de magistrados locales.

\section{Palabras clave}

Clunia, cueva-santuario, magistrados, Matres, religión doméstica, inscripciones rupestres.

\section{Abstract}

This paper offers an overview of religious expressions documented in the Roman city of Clunia, capital of the conventus Cluniensis, focusing on the "Cueva de Román", an underground sanctuary linked to the city's water supply where diverse cultic practices were conducted by local magistrates, amongst others.

\section{Key words:}

Clunia, cave-sanctuary, magistrates, Matres, domestic religion, rock inscriptions. 
Monográfico | Expresiones religiosas en las ciudades del poder de la Hispania Céltica: el caso de Clunia

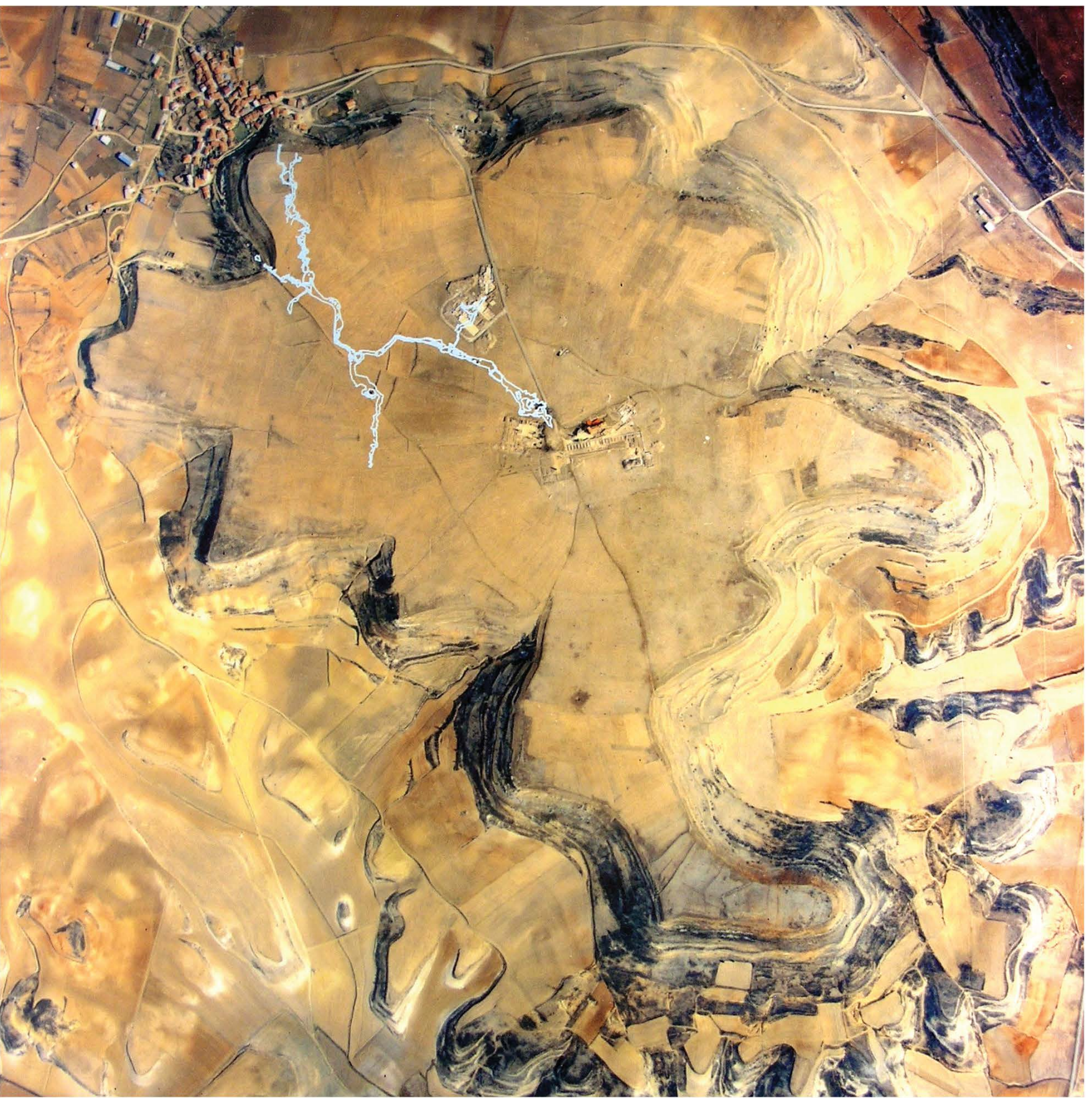

Fig. 1. Vista área de la meseta del «Alto de Castro» donde se ubica la ciudad romana de Clunia, y del complejo kárstico existente bajo el subsuelo urbano, conocido como «Cueva de Román» (foto Centro de Interpretación de Clunia). 
El estudio de las heterogéneas expresiones religiosas en las ciudades del poder de la Hispania Céltica -culto a divinidades indígenas y a dioses romanos, culto imperial, calendarios festivos, formas ceremoniales, personal especializado, tipología de espacios cultuales, etc.-, y el análisis de las complejas, multifacéticas y dinámicas relaciones entre poder y religión en esas mismas ciudades exigirían un desarrollo en profundidad que excede los límites de este artículo. Por ello, y dado que de otras sedes conventuales del área céltica hispana, o de aspectos religiosos concretos de las mismas se han ocupado con éxito otros investigadores en anteriores trabajos o en este mismo volumen, he considerado más conveniente centrar este trabajo en el estudio de las expresiones religiosas en Clunia, en Coruña del Conde (Burgos), la que fue sede del conventus Cluniensis (Plinio, Nat. Hist., 3.18) ${ }^{1}$.

Sabemos por Tito Livio, Per. 20, y Floro, 2.10.9, que la ciudad celtibérica de Clunia fue asediada en el año 74 a.C. durante el conflicto bélico entre Pompeyo y Sertorio, y que volvió a sufrir un nuevo asedio en el 56 a.C. en el contexto de una revuelta vaccea contra Roma, según relata Dion Casio, 39.54, aunque el asentamiento indígena no se emplazaba en la meseta del "Alto del Castro» donde se ubica la ciudad romana (fig. 1), sino en un cerro cercano conocido como «Alto del Cuerno», del que apenas se conocen datos.

Dado que en el solar de la Clunia romana no se han encontrado materiales anteriores al cambio de era, todo parece indicar que se trata de una ciudad creada ex novo en época tardoaugústea o tiberiana, que habría recibido posteriormente el epíteto de Sulpicia por parte de Galba debido a su conexión con los acontecimientos del año 68 d.C. Desafortunadamente, la escasez de excavaciones arqueológicas en esta sede conventual, la demora en la publicación de sus resultados y la procedencia descontextualizada de muchos de los hallazgos, convierten a Clunia en una de las ciudades del poder de la Céltica hispana peor conocidas, una carencia que se hace extensiva al ámbito de lo religioso ${ }^{2}$.

1. Quisiera agradecer a los evaluadores externos de este artículo sus interesantes comentarios, que sin duda han contribuido a mejorar este trabajo.

2. P. Palol, Clunia O. Studia varia clunensia, Burgos 1991; y Clunia. Historia de la ciudad y guía de las excavaciones, Burgos 1994; F. Tuset y M.A. de la Iglesia, “Clunia, centro de poder territorial”, en V.V.A.A., 


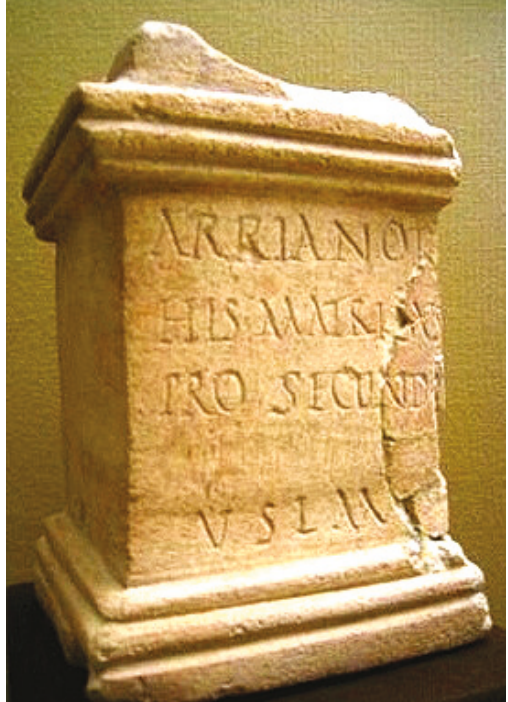

Fig. 2. Altar dedicado a las Matres hallado en Clunia (foto autora)
Aun así, se conoce la existencia de un templo dedicado a Júpiter en el foro de la ciudad, cuya construcción habría comenzado en época tardoaúgustea y/o tiberiana, y que actualmente se conserva en condiciones pésimas $^{3}$. También se han recuperado inscripciones votivas dedicadas tanto a dioses romanos como a deidades con teónimo indígena (fig. 2), que carecen en su mayoría de un contexto arqueológico preciso, con los problemas de cronología e interpretación que ello comporta ${ }^{4}$.

Algunas de ellas fueron descubiertas en ambientes domésticos, como, por ejemplo, el ara a las Matres hallada en el año 1959 durante la excavación de la estancia $n^{\circ} 3$ de la gran "casa $n^{\circ} 2$ », cuya funcionalidad se desconoce, en un contexto fechado en el siglo II d.C. ${ }^{5}$. Asimismo, ocho altares fueron descubiertos durante las excavaciones realizadas por Taracena entre 1932 y 1934 en la denominada «casa ${ }^{\circ} 1$ » (fig. 3), una vivienda de grandes dimensiones y lujosa decoración, con habitaciones rupestres semi-hipogeas y una com-

Patrimonio cultural y territorio en el Valle del Duero, Valladolid 2008, 63-73; L. Revell, Roman imperialism and local identities, Cambridge 2009, 62-67, 89, 93-96, 155-161, 176-178; M.A. de la Iglesia y F. Tuset, Colonia Clunia Sulpicia. Ciudad romana, Burgos 2012.

3. P. Palol, "Los edificios de culto en la ciudad de Clunia", Anas, 2/3, 1989-1990, 37-56; M.A. Gutiérrez y E. Subías, "El llamado templo de Júpiter de Clunia: una propuesta de restitución", AEspA, 73, 2000, 147-160; P. Palol y J.M. Guitart, Clunia VIII.1. Los grandes conjuntos públicos. El foro colonial de Clunia, Salamanca 2000, 143-158; W.E. Mierse, Temples and towns in Roman Iberia. The social and architectural dynamics of sanctuary designs from the third century B.C. to the third century A.D., Berkeley 1999, 175-176, 184-185, 196-197; L. Curchin, The romanization of Central Spain, London-New York 2004, 185-186; J. Irujo, "Sellos sobre material latericio de la Legio III macedónica en la colonia Clunia Sulpicia", Oppidum, 4, 2008, 92-112.

4. Palol y Vilella, Clunia II. La epigrafía de Clunia, Madrid 1987, 21-35: Diana (n ${ }^{\circ}$ 4, reutilizada en una casa de Peñalba de Castro); Neptunus ( $n^{\circ} 19-20$, reutilizada en la ermita y en excavación de la "casa $n^{\circ} 1$ ", respectivamente); Fortuna Redux ( $\mathrm{n}^{\circ}$ 6, en una casa de Coruña del Conde); Tutela (n ${ }^{\circ} 22$, ¿templo a Isis?); Minerva ( $\mathrm{n}^{\circ} 18$, hallada en el templo de Júpiter, y $\left.\mathrm{n}^{\circ} 24\right)$; Júpiter ( $\mathrm{n}^{\circ} 7-10$, add. 1 , y $\left.\mathrm{n}^{\circ} 210\right)$; Lares Viales $\left(\mathrm{n}^{\circ}\right.$ 11); Numen theatri ( $\mathrm{n}^{\circ}$ 21, encontrada en el teatro); Aiioragatus ( $\mathrm{n}^{\circ}$ 209, CIL II 2772); Divus Augustus ( $\mathrm{n}^{\circ}$ 212, CIL II 2778); ¿Divis? ( ${ }^{\circ} 5$, «casa $\left.\mathrm{n}^{\circ} 1 »\right) ;$ Matres (no 12-17, y no 211, CIL 2776); y otras árulas en las que resulta imposible leer el teónimo debido al estado de deterioro ( $\mathrm{n}^{\circ} 23-25$, «casa $\mathrm{n}^{\circ} 1$ »).

5. Palol y Vilella, op. cit., 1987, 30, nº 17; F. Beltrán y B. Díaz, "Altares con teónimos hispano-célticos de la Meseta Norte (Museos de Palencia, Burgos y Valladolid)", en M. Hainzmann (dir.), Auffer Sipren keltischer Götterverehrung, Viena 2007, 29-56, 35, n 2.2, fig. 8, leen Matrib(us)/ T(itus) Racili/us Valeri/anus ex vot(o); A. Pérez Ruíz, Al amparo de los Lares. El culto doméstico en las provincias romanas Bética y Tarraconense, Madrid 2014, 211, 324-325, 332, 340-341, figs. 204h, 208, 214, 222-223, y 438, tabla 1, no 49, 464, tabla 19, $\mathrm{n}^{\circ} 49,466$, tabla $20, \mathrm{n}^{\circ} 49, \mathrm{n}^{\circ}$ catálogo BU/Clunia09-I. 


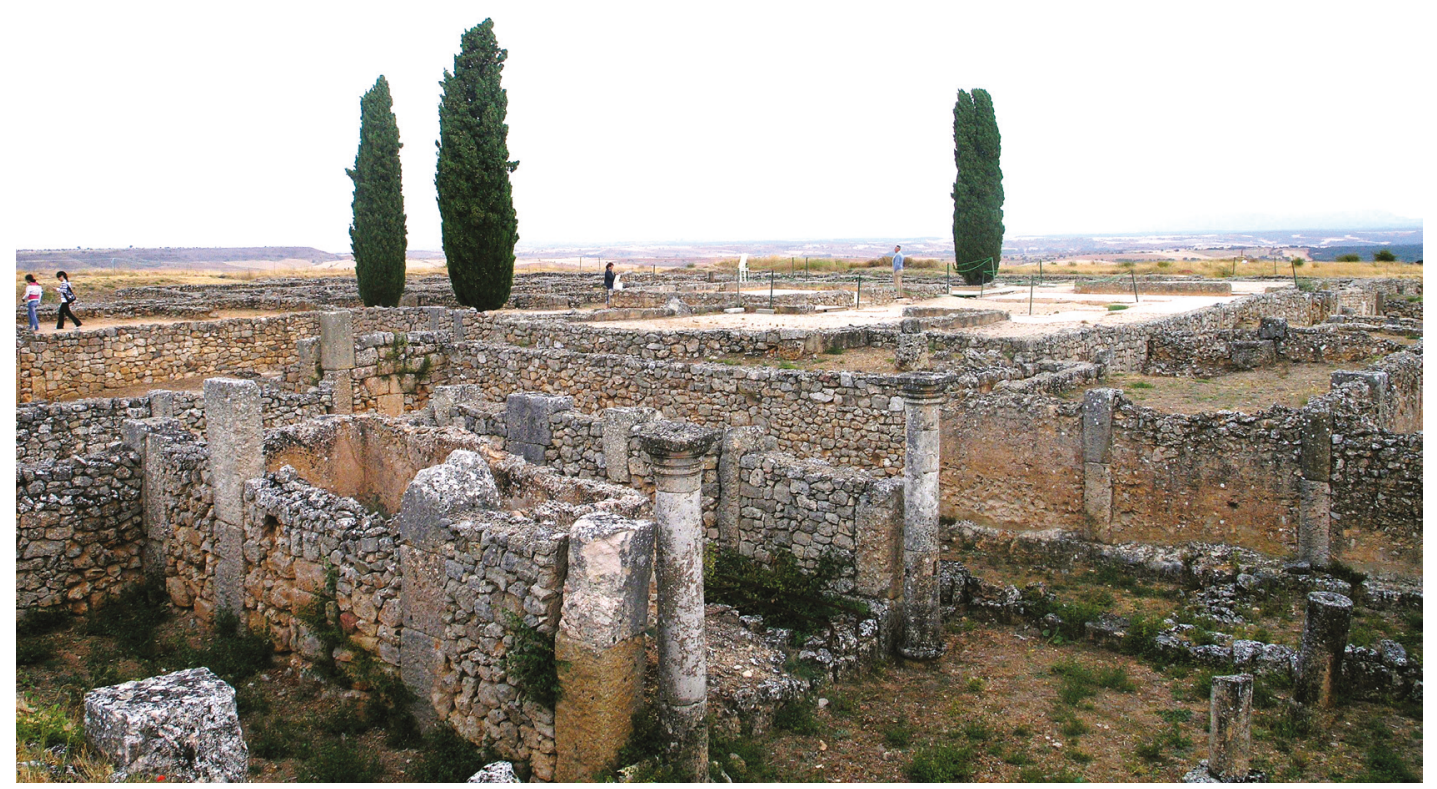

Fig. 3. La «casa no 1 » de Clunia (foto autora).

pleja planta articulada en torno a un patio central, que fue construida en época tiberiana y reformada en el siglo II d.C., cuando se le añadió un balneum construido parcialmente sobre la vía pública, sufriendo nuevas remodelaciones en los siglos III-IV d.C. ${ }^{6}$. Debido a esas sucesivas transformaciones y a la propia metodología arqueológica seguida por Taracena, la interpretación de la estratigrafía de esta vivienda y de los materiales hallados en ella resulta muy problemática. Si a ello se suma el hecho de que los datos publicados son parciales, confusos y contradictorios, no es de extrañar que resulte muy difícil determinar los contextos precisos de uso y de depósito de estas inscripciones votivas ${ }^{7}$.

6. Sobre la «casa no 1» y la epigrafía asociada, vid. B. Taracena, "El palacio romano de Clunia", AEspA, 19, 1946, 29-69; Palol, op. cit., 1994, 46-48, figs. 37-42; V. García-Entero, Los balnea domésticos -ámbito rural y urbano- en la Hispania Romana, Madrid 2005, 215-218; S. Alfayé, Santuarios y rituales en la Hispania Céltica, Oxford 2009, 59-60; Pérez Ruíz, op. cit., 325, 332, 337-338, figs. 204a-d, 205b-c, 208, 222-223, y 463464, tabla 19, no 43-48, 466, tabla 20, n 43-48

7. Aunque Pérez Ruíz, op. cit., 463-464, tabla 19, n 43-48, atribuya una ubicación indefinida a cuatro de las cinco aras encontradas en la «casa $n^{\circ} 1$ » incluidas en su estudio -con la excepción de la dedicada a I.O.M., que procedería de una zona subterránea de servicio-, lo cierto es que la revisión de la documentación 
Pese a ello, sabemos que en una habitación se encontraron tres aras adosadas a la pared: una dedicada a las Matres $^{8}$ (fig. 2), otra consagrada a Neptuno ${ }^{9}$, y un tercer altar cuyo campo epigráfico está tan deteriorado que resulta imposible leer el teónimo ${ }^{10}$. Además, un altar con la fórmula votiva $\operatorname{sac}(\mathrm{rum})$ fue descubierto sobre el suelo de la estancia $\mathrm{n}^{\circ} 59$, identificada como la cocina de la vivienda ${ }^{11}$. También sobre el suelo, aunque en este caso el de la habitación subterránea $\mathrm{n}^{\circ} 36$, se recuperó un ara dedicada a I.O.M., junto con otros materiales que parecían provenir del piso superior ${ }^{12}$. Una sexta árula, de lectura conflictiva ( ${ }^{\text {Divis}}$ ?), formaba parte del muro de la cloaca de la «casa $n^{\circ} 1 »$, lo que revela que fue reutilizada como material de construcción ya en época antigua, seguramente durante alguna de las reformas y modificaciones que sufrió la vivienda ${ }^{13}$. Dos altares más fueron descubiertos durante la excavación de esa casa en los años 1932 y 1933, aunque estén tan desgastados que en ellos no puede reconocerse el teónimo ${ }^{14}$.

publicada permite identificar el contexto de hallazgo de esas piezas dentro de la vivienda, aunque éste resulte demasiado vago.

8. Palol y Vilella, op. cit., 1987, 30, nº 16, ofrecen la lectura Arria Not/his Matribus /pro Secundo/ v(otum) $s$ (olvit) l(ibens) $m$ (erito), que es seguida por J. Gómez Pantoja, "Las Madres de Clunia", en F. Villar y F. Beltrán (Eds.), Pueblos, lenguas y culturas en la Hispania prerromana, Universidad de Salamanca, Salamanca 1999, 421-432 (especialmente 423, 6e); y por Beltrán y Díaz, loc. cit., 35-36, nº 2.3, fig. 9, que la datan en el siglo II d.C. En cambio, M.L. Albertos, Organizaciones suprafamiliares en la Hispania Céltica, Valladolid 1976, 60, prefiere leer la 1. 2 como his Matribus, «éstas, las de aquí, al igual que J.M. Solana y L. Hernández, Religión y sociedad en época romana en la Meseta septentrional, Valladolid 2000, 160-161 y 279, nº 171, quienes leen la 1. 1 como Arria Not(ia). Cf. también Alfayé, op. cit., 2009, 59, n. 191; Pérez Ruíz, op. cit., $201,211,325,332,340-341,343$, figs. 204b, 213, 222-223, y 369-371, fig. 10, y 420,463 , tabla $19, \mathrm{n}^{\circ} 44, \mathrm{n}^{\circ}$ catálogo BU/Clunia04-I.

9. Palol y Vilella, op. cit., 1987, 32, no 20; Pérez Ruíz, op. cit., 338, fig. 222, considera que ésta sería una lectura arriesgada. Cf. también Alfayé, op. cit., 59, n. 192.

10. Palol y Vilella, op. cit., 1987, 34, no 25; Pérez Ruíz, op. cit., 338.

11. Taracena, op. cit., 55-57, fig. 24; Palol y Vilella, op. cit., 1987, 35, no 26; Alfayé, op. cit., 2009, 59; Pérez Ruíz, op. cit., 337, 342-343, fig. 223, y p. 464, tabla 19, nº 48, fechándola en los siglos I-II d.C. Sobre la presencia de elementos cultuales en las cocinas romanas, vid., entre otros, W. Van Andringa, Quotidien des dieux et des hommes. La vie religieuse dans les cités du Vésuve à l'époque romaine, Roma 2009, 217-269; y A. Dubourdieu, "Les cultes domestiques dans le monde romain", ThesCRA, VIII, Los Angeles 2012, 32-43; Pérez Ruíz, op. cit., 94-102, fig. 91.

12. Taracena, op. cit., 46 y 65, fig. 23, no 4; Palol y Vilella, op. cit., 1987, 25, no 9; Pérez Ruíz, op. cit., 323-325, figs. 204a y 208 , y 463 , tabla $19, n^{\circ} 43$, identifica esa dependencia subterránea como una zona de servicio

13. Palol y Vilella, op. cit., 1987, 22, no 5; Solana y Hernández, op. cit., 195, 303, nº 262. En cambio, Beltrán y Díaz, loc. cit., 39-41, no 3.3, figs. 19-22, señalan la dudosa condición de teónimo de Divis, y proponen la lectura Iulia (et)/Dives/ pro eo/ru(m) aun(culo)/ ex v(oto) o bien ex v(oto) s(olverunt), datándola en los siglos II-III d.C.

14. Palol y Vilella, op. cit., 1987, 34, no 23-24; M. Rodríguez y J. Salido, "Fragmento de ara (re)construída procedente de Clunia (Burgos)", Ficheiro Epigráfico, 112, 2013, n 485, con la lectura A+/ [-]a+[-]/---; y Pérez Ruíz, op. cit., 338. 
Además de las prácticas atestiguadas en la «casa $n^{\circ} 1$ », otro ejemplo de religión doméstica en la ciudad de Clunia lo ofrece la estancia $n^{\circ} 6$ de la «casa $n^{\circ} 3 »$-también denominada "casa triangular»-, que ha sido identificada como un sacrarium sobre la base de la existencia de un larario de podio adosado a la pared y rodeado por un pavimento teselado, aunque no podamos precisar el tipo de actividades cultuales celebradas en ese espacio entre los siglos I-III d.C. ${ }^{15}$. Otro sacrarium ha sido exhumado en el peristilo de la denominada «casa de las Cuevas Ciegas», fechándolo A. Pérez Ruíz en el siglo I d.C. ${ }^{16}$.

Es posible que otros elementos hallados en Clunia deban ser también interpretados como indicadores de la celebración de prácticas religiosas en la sede conventual, como es el caso de las terracotas halladas en la excavaciones de B. Taracena que se exponen actualmente en el Museo de Burgos, y que dimos a conocer en otro trabajo (fig. 4). Se trata de varios fragmentos de figuras humanas vestidas con manto talar y una capucha cónica (cucullus) que únicamente deja visible el óvalo del rostro, con orificios de suspensión y posible datación altoimperial; sin embargo, una vez más la falta de información sobre la procedencia y el contexto arqueológico preciso de estas piezas impide avanzar en su interpretación y/o su asociación con un posible espacio de culto público o privado ${ }^{17}$.

Asimismo, en esta sede conventual existió un santuario subterráneo conocido como «Cueva de Román» (figs. 1, 5-9), en cuyo estudio se centra este trabajo dado que muestra la participación de magistrados locales en las actividades religiosas de la ciudad, y atestigua la importancia de los espacios rupestres de culto en época romana, hasta la fecha poco valorados y asociados con excesiva frecuencia a expresiones religiosas espontáneas individuales sin vocación de publicidad ni audiencia ${ }^{18}$. Además, el estudio de esta cueva-santuario ejem-

15. Palol, op. cit., 1994, 76-81; M. Bassani, "Ambienti e edifici di culto domestici nella Peninsola Iberica" Pyrenae, 36, 1, 2005, 71-116 (especialmente 81-83, 87, 89, 91, figs. 8-9); Pérez Ruíz, op. cit., 215-217, 222224, figs. 2-3, 5 y 12, 237-238, fig. 43, 247, 249, fig. 83, 254-255, 258-259, 275, fig. 122, y 383-385, fig. 36, y $411,420,438$, tabla $1, n^{\circ} 41-41.1,448$, tabla 2 , no $41-41.1,453$, tabla $7, n^{\circ} 41$.

16. Pérez Ruíz, op. cit., 215-217, figs. 2-3 y 5, 252-255, figs. 85-86 y 90-91, 258, 270-271, 379-383, fig. 27, 438 , tabla $1, \mathrm{n}^{\circ} 42$, y 453 , tabla $7, \mathrm{n}^{\circ} 42$.

17. Cuatro fragmentos han sido realizados mediante molde bivalvo, mientras que otro, realizado a mano, parece ser una imitación de esas piezas; sobre sus paralelos y las diversas posibilidades de interpretación, cf. S. Alfayé, op. cit., 2009, 370-371, 375, figs. 206-208; e Imagen y ritual en la Céltica peninsular, A Coruña 2011, 50-58, 92, 97-98, 113, 118-120, figs. 1, 9, 16, 19-24. Sobre otras figurillas antropomorfas de posible uso cultual halladas en Clunia, vid. fig. 4, y Alfayé, op. cit. 2009, 362-363.

18. Sobre estas cuestiones, cf. P. Veyne, “Titulus praelatus: offrande, solennisation et publicité dans le exvoto gréco-romain", Revue Archéologique, 2, 1983, 235-274; M. Beard, "Writing and religion: ancient literacy and the function of the written Word in Roman Religion", en V.V.A.A., Literacy in the Roman World, Michigan, 1991, 35-58; S. Alfayé y F. Marco, "Religion, language and identity in Hispania: Celtiberian and Lusitanian Rock inscriptions”, en R. Haussler (dir.), Romanisation et epigraphie. Etudes interdisciplinaires sur l'acculturation et l' identité dans l' Empire romain, Montagnac 2008, 281-306; S. Alfayé, op. cit., 2009, 32-123; EAD., "Hacia el lugar de los dioses: aproximación a la peregrinación religiosa en la Hispania indoeuropea", en F. Marco, F. Pina y J. Remesal (Eds.), Viajeros, peregrinos y aventureros en el mundo antiguo, Barcelona 2010, 177-218; J.A. Baird y C. Taylor (Eds.), Ancient graffiti in context, New York-London 2011; P. Keegan, Graffiti in Antiquity, London-New York 2014, 86-113. 


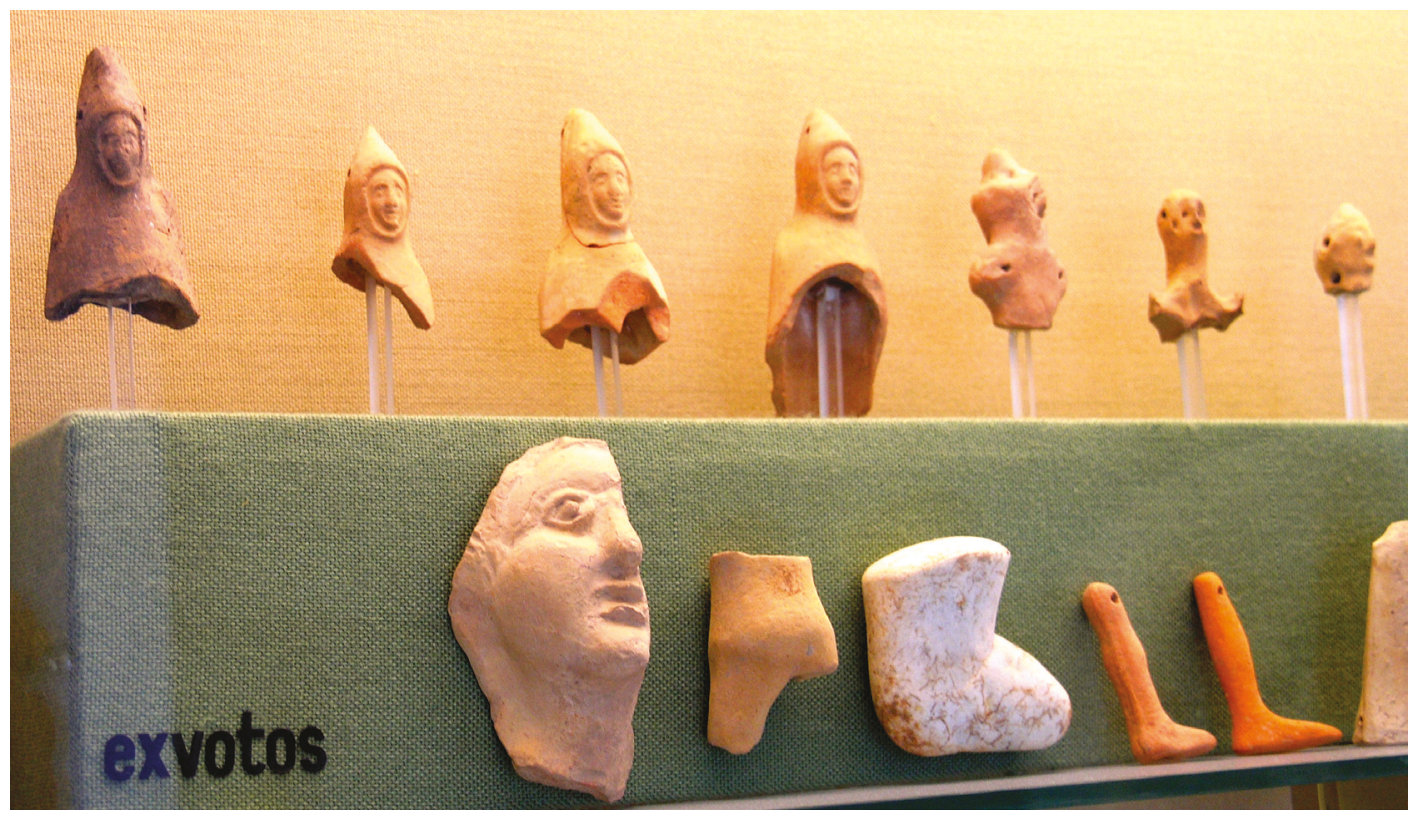

Fig. 4. Terracotas procedentes de Clunia expuestas actualmente en el Museo Arqueológico de Burgos (foto autora).

plifica los problemas documentales y metodológicos a los que nos enfrentamos a la hora de estudiar las manifestaciones rituales en las ciudades del poder de la Hispania Céltica -falta de información, publicación provisional de los materiales, inscripciones necesitadas de revisión, etc.-, y, en último extremo, muestra la diversidad de las prácticas religiosas que tenían cabida en una sede conventual hispana.

\section{El santuario subterráneo de la «cueva de Román»}

Bajo la meseta en la que se emplaza la Clunia romana existe un complejo kárstico con diversos lagos y galerías (fig. 1), que en época romana fue acondicionado mediante canalizaciones, diques y pozos para mantener un nivel constante de reserva hídrica y abastecer con ella a la población, y al que se podía acceder desde diversos puntos del entramado urbano a través de túneles y de pozos de captación, control y ventilación. En el año 1913 V. Hinojal estudió una parte de esa red de galerías subterráneas, aunque su exploración espeleológica completa se debe a las campañas dirigidas por P. Palol y J. Vilella a comienzo de los años 80 del pasado siglo, durante la cual se descubrieron en el tramo final unas cuarenta inscripciones latinas, 


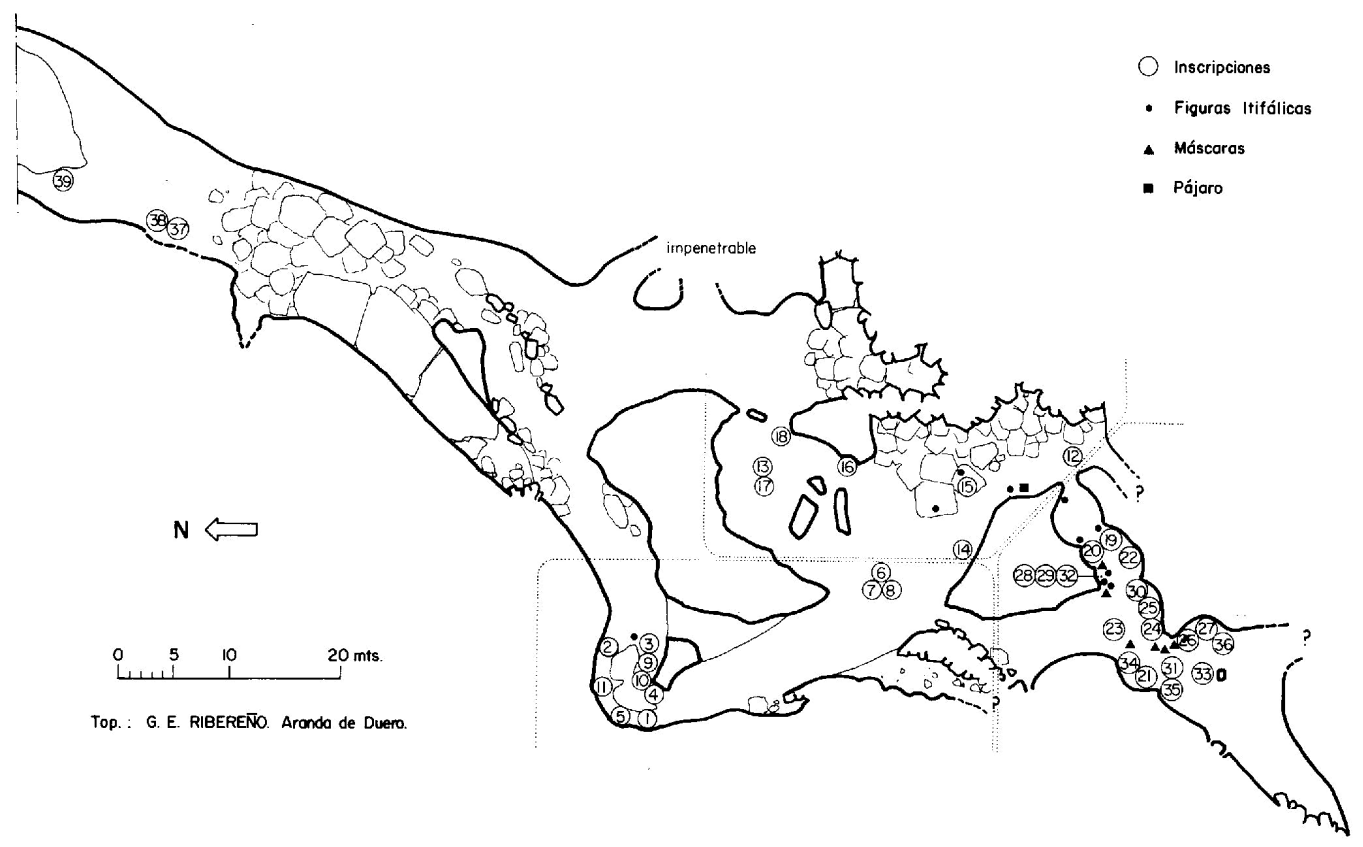

Fig. 5. Topografía del santuario hipogeo cluniense (según Palol y Vilella 1987).

numerosos grabados y figurillas de barro, lo que motivó la identificación de ese espacio como un santuario subterráneo (figs. 1 y 5-9).

El tramo del santuario es una cavidad laberíntica de aproximadamente $150 \mathrm{~m}$. de largo x $20 \mathrm{~m}$. de ancho, con una altura que oscila entre los 0,5 y $2 \mathrm{~m}$. -aunque la altura libre predominante es $1 \mathrm{~m}$.-, que conserva una importante sedimentación de arcilla fina y en la que, salvo en una pequeña charca, no existe agua (fig. 5). Las dificultades actuales de acceso a ese espacio - tres horas de difícil recorrido desde la entrada situada a $650 \mathrm{~m}$, en la zona denominada «Cuevas Ciegas»-, así como la falta de luz, los cambios en el nivel freático y las propias características de los testimonios antiguos -fragilidad, superposición de inscripciones, cuarteamiento del barro (figs. 7-8)- han dificultado el avance de la exploración y retrasado la publicación de un estudio definitivo de este santuario, todavía por realizarse. De hecho, hasta el momento sólo conocemos la documentación publicada en los trabajos preliminares de Palol y Vilella en 1986 y 1987, que no permiten llegar a conclusiones definitivas sobre el funcionamiento de ese espacio de culto y plantean numerosos interrogantes sobre su período de frecuentación, el tipo de prácticas celebradas allí, la(s) divinidad(es) a la(s) que estaba consagrado, o las razones de la presencia de magistrados en el subsuelo, entre otras cues- 


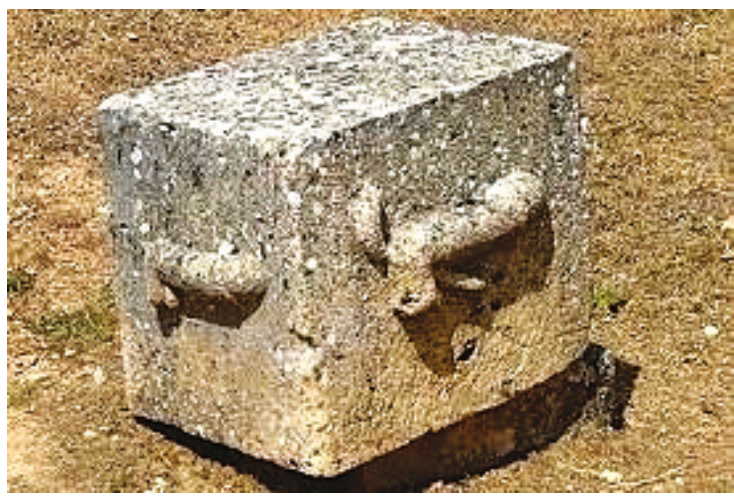

Fig. 6. Sillar decorado con motivos fálicos, recuperado junto al cardo oeste en la «casa $\mathrm{n}^{\circ} 1$ » de Clunia; actualmente se encuentra desaparecido (foto autora).

tiones. Aun así, quisiera proponer aquí algunas hipótesis provisionales sobre esta singular cueva-santuario existente bajo la ciudad romana ${ }^{19}$.

\section{El acceso al santuario y los itinerarios dentro de la cavidad}

Sobre la base de la información publicada hasta la fecha, se piensa que en el siglo I d.C. el acceso al santuario subterráneo pudo realizarse a través de varios pozos localizados cerca de éste, en un área situada entre el foro y la «casa $n^{\circ} 1 »$ : se trata de los pozos denominados D1D6, que miden $1,8 \mathrm{~m}$ de diámetro, alcanzan los $20 \mathrm{~m}$ de profundidad, y actualmente se encuentran colmatados. De ellos, los pozos más próximos al santuario son D5 y D6, localizándose a cada lado del tramo final de la gran galería que precede al santuario (fig. 5), por lo que es posible que el descenso se hiciera a través de ellos ${ }^{20}$. Desconocemos qué estructuras de la superficie pudieron estar asociadas a esas entradas al inframundo, pero cabe pensar que esos

19. Sobre la «cueva de Román», vid. P. Palol y J. Vilella, “¿Un santuario priápico en Clunia?”, Koiné, 2, 1986, 15-25; EAD., op. cit., 1987, 129-155; L. Gasperini, "Sobre el hipogeo cluniense de la Cueva de Román y sus inscripciones”, en J. Mangas y J. Alvar (Eds.), Homenaje a J.M. Blázquez, V, Madrid 1998, 161-182; Gómez Pantoja, loc. cit., 427-430; Alfayé, op. cit., 2009, 59-60; y loc. cit., 2010, 206-213; R. Cuesta, "Cueva Román: fuente de abastecimiento, lugar de culto de la Colonia Clunia Sulpicia”, en A. Costa et alii (coord.), Aquae sacrae: agua y sacralidad en época romana, Gerona 2011, 167-180.

20. Palol y Vilella, loc. cit., 1986, 20-23; EAD., op. cit., 1987, figs. 2a-c. 
accesos estaban controlados por las autoridades (civiles y/o religiosas), y que formaban parte de algún tipo de recinto o construcción cultual pública, cuestiones que futuras excavaciones de esa zona y de esos pozos podrían resolver. En este sentido, Palol y Vilella ya plantearon que la ubicación de la cueva pudiera estar señalizada topográficamente en el entramado urbano mediante bloques decorados con falos y tridentes como los hallados en la «casa $n^{\circ} 1$ " (fig. 6), cuya localización en superficie se correspondería aproximadamente con la del santuario subterráneo (figs. 1, 5). Se trata de un bloque prismático decorado con un falo en erección con cuartos traseros y cola de animal en sendas caras, que fue hallado junto al cardo oeste, donde se conservaba in situ hasta su reciente robo (fig. 6); y de otro bloque que muestra un falo por una cara y un tridente por la otra, que fue amortizado en la reconstrucción tardía del criptopórtico de la vivienda «n $n^{\circ} 1 »^{21}$. La iconografía de estas piezas podría aludir tanto a la existencia de la reserva hídrica del subsuelo -el tridente es el atributo de la deidad acuática Neptuno, a quien se dedicaron en Clunia dos aras, la ya mencionada de la «casa no 1 » y otra descubierta en época moderna cerca de la ermita de Nuestra Señora de Castro ${ }^{22}$-, como a la actividad cultual vinculada al falo celebrada en la cavidad ( $v i d$. infra). Por ello, resulta plausible pensar que nos encontremos ante los indicadores visuales en superficie de la ubicación subterránea de la cueva, aunque quizás no debamos descartar tampoco una funcionalidad profiláctica -no excluyente- de estas imágenes fálicas (fig. 6), ampliamente documentada en el mundo antiguo, incluida Hispania ${ }^{23}$.

Quienes accedieron al santuario hipogeo por los pozos o bien fueron descolgados mediante cuerdas, o descendieron por su propio pie apoyándose en huecos alternos realizados en las paredes, como los que muestran otros pozos de la ciudad. En cualquier caso, las sensaciones que experimentaran durante el angosto descenso provocarían una ruptura con la realidad conocida y una preparación psicosomática para la experiencia religiosa que iban a vivir en una topografía ya de por sí extraordinaria como era la propia cueva, predisponién-

21. Palol y Vilella, op. cit., 1987, 132; Palol, op. cit.,114-118, figs. 155-157; Gómez Pantoja, loc. cit., 429; C. Vargas, "Estudio del motivo fálico hallado en el edificio romano republicano bajo el podio de Banderas", Apuntes del Real Alcázar de Sevilla 12, 2011, 106-121 (especialmente 112-115, 119), identifica la cola animal de los falos que decoran el sillar hallado en el cardo oeste como una cola de león, y relaciona esa iconografía con una representación fálica sobre sillar arquitectónico del siglo I a.C. hallada en el Alcázar de Sevilla.

22. J. Lopérraez, Descripción histórica del Obispado de Osma con tres disertaciones sobre los sitios de Numancia, Uxama y Clunia, vol. II, Madrid 1788, 358-359; Palol y Vilella, op. cit., 1987, 31, no 19.

23. Cf., entre otros, C. Johns, Sex or symbol? Erotic image of Greece and Rome, New York 1982, 62-75; J.A. Mínguez, "Decoraciones fálicas sobre vasos cerámicos de época romana de la Península Ibérica", Zephyrus, 49, 1996, 305-319; A. Veyrac, "Redécouverte de deux phallus sur la face occidentale du pont du Gard”, en A. Bouet y F. Verdin (dirs.), Territories et paysages de l'Âge du Fer au Moyen Àge. Mèlanges offerts à Philippe Leveau, Bordeaux 2005, 285-293, figs. 1-15; C. Moser, Naked Power. The phallus as an apotropaic symbol in the images and texts of Roman Italy, Pennysilvania 2006, figs. 1, 12-13, 37-60; Vargas, loc. cit., 106-121 (especialmente 108-110, 116-120), con un catálogo de los falos romanos representados sobre soporte pétreo en el que, sin embargo, no incluye el que decora el sillar encontrado en el criptopórtico de la cluniense «casa $n^{\circ} 1 » ;$ J.R. Clarke, "Sexuality and visual representation", en T.R. Hubbard (ed.), Greek and Roman sexualities, Oxford 2013, 509-533 (especialmente 524-525). 


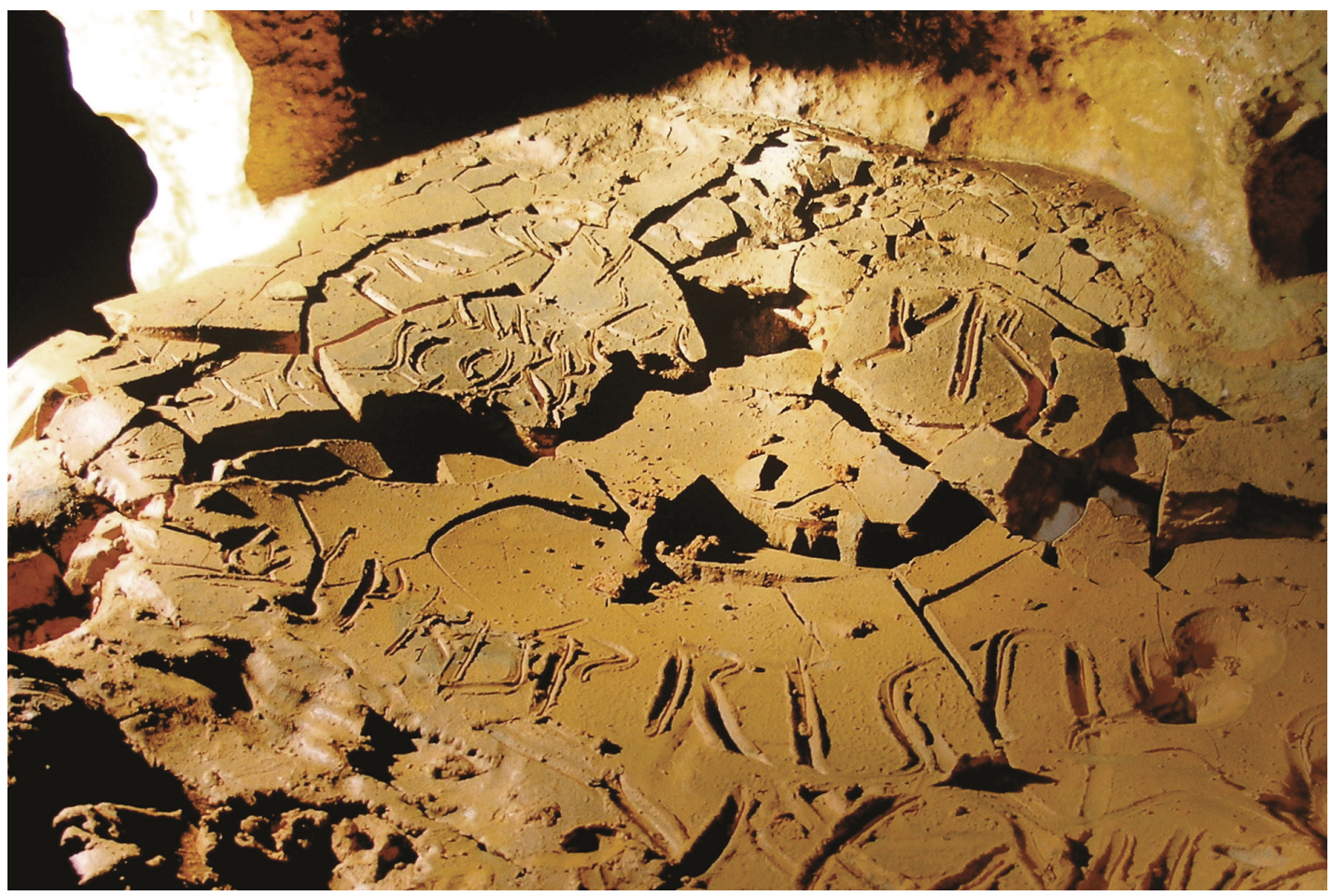

Fig. 7. Epígrafe latino $\mathrm{S} 2$ realizado sobre el barro de la «Cueva de Román» (foto Centro de Interpretación de Clunia).

dolos para el contacto con lo divino ${ }^{24}$. Sin embargo, no hay que descartar que existiera otra forma más sencilla de acceder a la cueva en época romana, quizás descendiendo por otros pozos menos dificultosos, o bien atravesando la zona que continúa después de la «sala 2» del santuario (fig. 5), y que no ha sido explorada en las diversas campañas arqueo-espeleológicas para no alterar los frágiles restos romanos.

24. Sobre la cueva como topografía para la práctica del ritual, vid. J.E. Brady y K.M. Prufer (Eds.), In the maw of the Earth Monster. Mesoamerican Ritual Cave Use, Austin 2005; K.M. Prufer y J.E. Brady (Eds.), Stone houses and Earth Lords. Maya religion in the cave context, Colorado 2005; J. Zilhao, The archaeology of caves, shelters and the deep karst, World Archaeology, 29, 8, 2009; Alfayé, op. cit., 2009, 30-123; y loc. cit., 2010, 177-218; K. A. Bergsvik y R. Skeates (Eds.), Caves in context. The cultural significance of caves and rock-shelters in Europe, Oxford 2012; H. Moyes (Ed.), Sacred darkness. A global perspective on the ritual use of caves, Colorado, 2012; C. Rísquez y C. Rueda (Eds.), Santuarios iberos: territorio, ritualidad y memoria. Actas del congreso El santuario de la cueva de La Lobera, Jaén 2013; M. Dowd y R. Hensey (Eds.), The Archaeology of Darkness, Oxford 2016. 


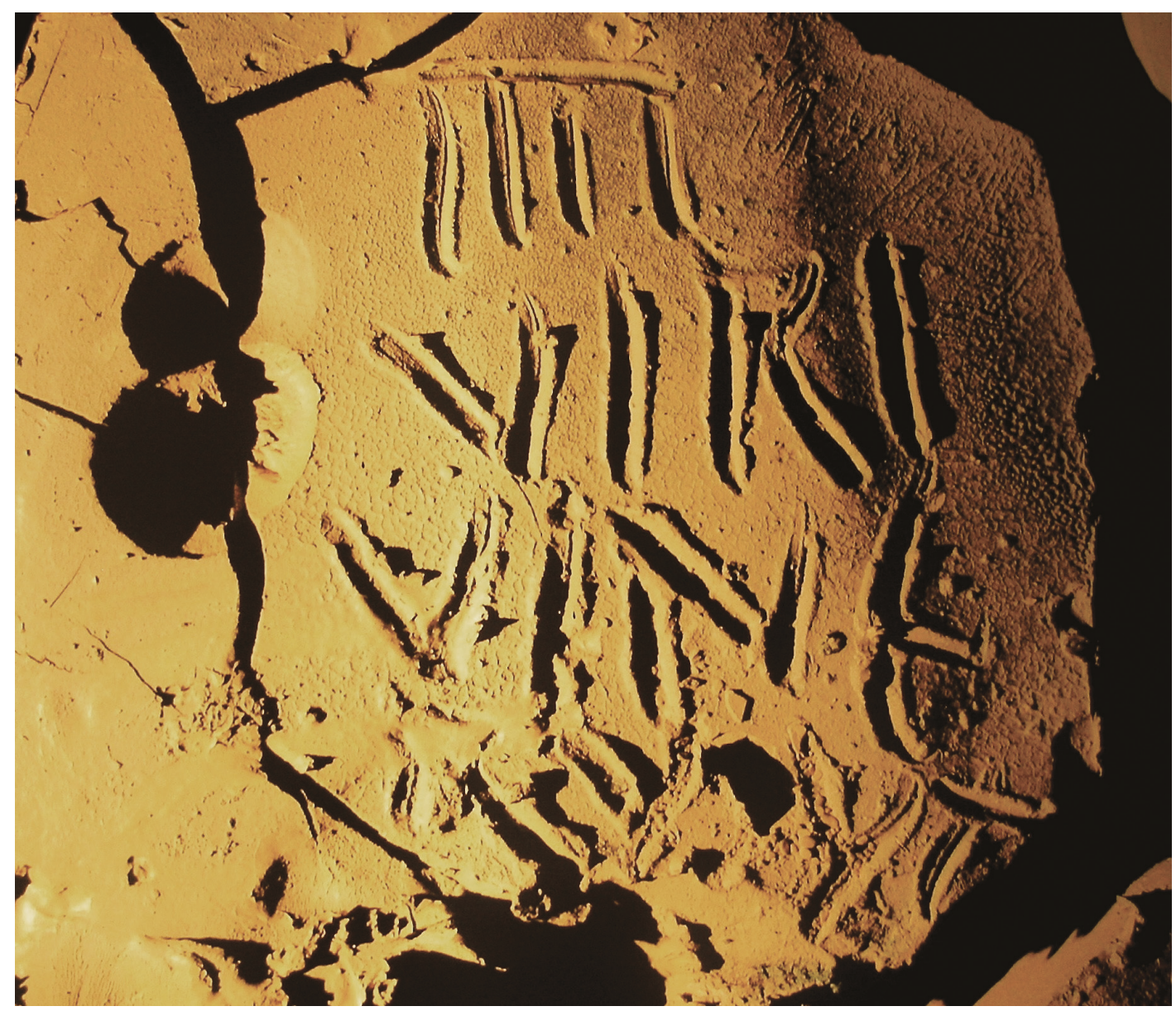

Fig. 8. La inscripción latina S13, III/viri/ vene/runt, de la cueva-santuario (foto Centro de Interpretación de Clunia).

Si realmente el acceso al subsuelo se produjo por los pozos D5 y D6, una vez dentro de la cueva había que recorrer un pequeño tramo de la galería principal antes de llegar al santuario, que fue muy frecuentado a juzgar por las numerosas pisadas conservadas -tanto huellas de calzado como de pies descalzos-, improntas de tejidos, cenizas, restos de antorchas, grabados fálicos e inscripciones (S37-39) descubiertos en ese área ${ }^{25}$. Avanzando por la galería se llega a un espacio del que parten dos divertículos que confluyen en un espacio cen-

25. Palol y Vilella, loc. cit., 1986, 19 y 131, figs. 2b-c. 
tral, denominado «sala 1», desde el que a su vez se accede a otras dos galerías que convergen nuevamente en otra sala, la «sala 2 », en la que se concentran la mayoría de inscripciones y figurillas; se desconoce la topografía de la cueva más allá de esa zona (fig. 5). Sobre la base de la documentación publicada, se observa una distribución diferenciada de las agrupaciones de artefactos -epígrafes, grabados y coroplastia- en los diversos tramos de la cavidad (figs. 5 y 7-9), que podría responder tanto a la existencia de itinerarios variados, como a la utilización diferencial de la cavidad ligada a una gradación cualitativa en la consideración sagrada de los diversos tramos y/o a la realización de prácticas cultuales específicas en áreas determinadas del santuario, o quizás también a variaciones temporales en la frecuentación y los usos de esa cueva, que comportaron formas distintas de transitar por ese espacio ${ }^{26}$.

Partiendo desde la galería principal, uno podía adentrarse en el santuario por el divertículo W, en cuyo tramo central existe una «pequeña charca de agua» en torno a la que se grabaron un falo y ocho inscripciones (S1-S5, S9-11), una de las cuales fue realizada por el quattuorvir Fabricius (S1a-b), y otras tres por el aedilis cluniense Bergius Seranus (S2-S4) ${ }^{27}$ (fig. 7). La concentración de esas inscripciones en torno al único punto de agua del santuario no parece ser casual (fig. 5) y podría responder a su uso como topografía focal de las prácticas cultuales celebradas en esa galería, ya sea porque se atribuyeran propiedades extraordinarias al lodo y/o al agua extraídos de esa poza, o bien porque en ella tuviera lugar el depósito de ofrendas en un contexto acuático, una práctica ampliamente atestiguada en otras cuevassantuario del mundo antiguo ${ }^{28}$. Otro posible itinerario sería el seguido por quienes, desde la galería principal, se internaron en el divertículo E; éste fue el camino que recorrieron los quattuorviri (S13) (fig. 8) y Priscus, quien grabó tres inscripciones en ese sector de la cavidad (S16-18). Al igual que sucede en el divertículo W, no se han hallado figuras grabadas ni elementos de coroplastia en esta zona ${ }^{29}$ (fig. 5).

Los dos divertículos $\mathrm{E}$ y W confluyen en un espacio amplio denominado «sala 1», en cuya zona central se realizaron varias inscripciones (S6-S8, S14), y del que parten otras dos galerías, aunque la $\mathrm{W}$ no parece haber sido muy transitada dada la inexistencia de manifestaciones rupestres antiguas ${ }^{30}$ (fig. 5). Si se avanza por la galería E, encontramos estatuillas itifálicas y un vaso de barro sobre el que se grabó la inscripción Carisius Ocu[---] (S15); en la pared contraria se documenta una inscripción (S12), y justo antes de la entrada a un estrecho divertículo hay un falo y un pájaro modelados en barro que fueron depositados sobre el suelo. El acceso a ese corredor estaba, además, flanqueado por dos falos de barro de gran tamaño - uno modelado $(63 \times 15 \mathrm{~cm})$, y otro realizado en altorrelieve sobre una placa blanda de arcilla-, sobre los que se grabaron sendas inscripciones (S19-20) y que, posiblemente, señalizaban la entrada a la zona más sagrada del santuario, la «sala 2», donde se concentran la mayoría de epígrafes y coroplastia. A lo largo de las paredes de esta angosta galería se docu-

26. Palol y Vilella, op. cit., 1987, fig. 2c.

27. Palol y Vilella, op. cit., 1987, 130, 132-133, figs. 2c y 14-22.

28. Cf. diversos paralelos en Alfayé, op. cit., 2009, 30, 62-63, n. 222, y 336-338.

29. Palol y Vilella, op. cit., 1987, 133-134, figs. 2c y 24.

30. Palol y Vilella, loc. cit., 1986, 20-21; EAD., op. cit., 1987, 132-133. 


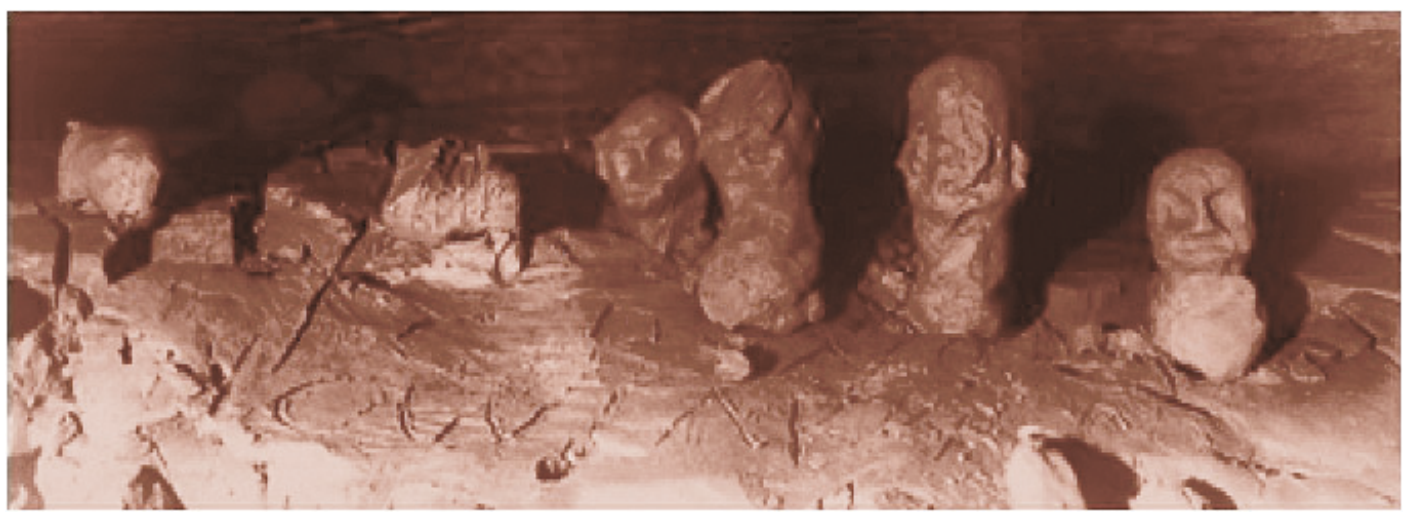

Fig. 9. Bustos modelados en barro y colocados sobre una repisa natural de la «Cueva de Román» (foto Centro de Interpretación de Clunia)

mentan epígrafes (S22, S28-29, S32), rostros humanos y bustos realizados mediante técnicas diversas, y falos de barro que originalmente se mantenían erguidos en las repisas naturales existentes junto a la pared ${ }^{31}$ (figs. 5 y 9 ).

Tras atravesar este divertículo se llega a la denominada «sala 2», que parece haber tenido una importancia especial debido a la gran concentración de inscripciones (S21, 23-27, 30-31, 33-37) realizadas sobre una amplia repisa natural, y a la existencia de numerosas cabezas y bustos humanos modelados en barro (fig. 9), uno de los cuales, barbado, destaca por su cuidada ejecución y su preeminente colocación, sin que por el momento sepamos qué significado atribuir a tan visible ubicación: ¿ ¿representa a un devoto o podría tratarse de la imagen de culto de la deidad del santuario?32. Dado que no se ha continuado la exploración espeleológica más allá de esta sala (fig. 5), no sabemos si el santuario continuaba en esa zona, y/o si había otro acceso a la superficie atravesando esa área que hiciera innecesario el retorno por el mismo itinerario.

\section{La(s) deidad(es) subterránea(s) cluniense(s)}

Curiosamente, en ninguna de las inscripciones hipogeas publicadas hasta el momento se menciona el nombre de la(s) deidad(es) a la(s) que estaba consagrado este espacio cultual. Esta reiterada omisión teonímica, que podría responder a algún tipo de tabú religioso, muestra en cualquier caso la voluntad de los visitantes por privilegiar el registro autógrafo de su nombre por encima del de la divinidad, en muchos casos acompañado de diferentes

31. Palol y Vilella, op. cit., 1987, 130-131, 133-135, figs. 2-6, 8-10, 12-13, 23, 25-30, 32, 35-36, 39.

32. Palol y Vilella, op. cit., 1987, 131, 134-135, figs. 2b-c, 5-8, 11, 31, 33-34, 37-38, 40. 


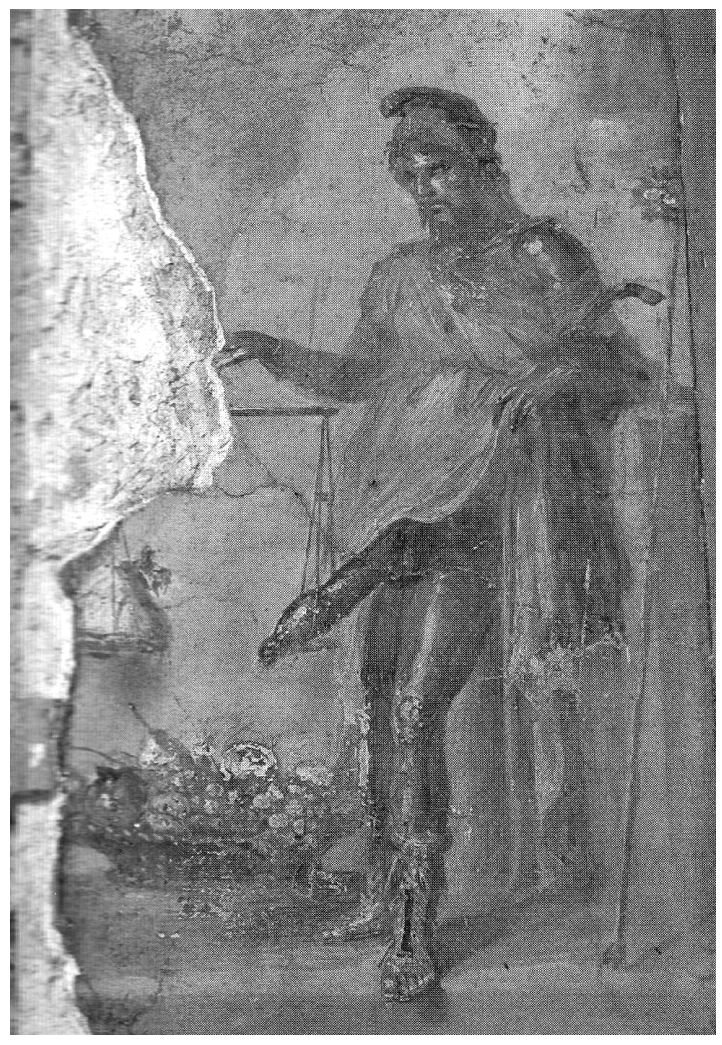

Fig. 10. Pintura parietal del dios Príapo en las fauces de la Casa dei Vetti, Pompeya, siglo I d.C. (foto Pérez Ruíz, op. cit.). formas del verbo venio, lo que es habitual en las inscripciones realizadas en contextos religiosos rupestres ${ }^{33}$.

Dada la proliferación de figurillas fálicas, Palol y Vilella interpretaron provisionalmente este espacio como un «santuario priápico» al que habrían descendido los devotos en busca de curación para sus órganos sexuales mediante el uso medicinal del barro, y/o también con el fin de propiciar la fecundidad -la suya propia y la de la comunidad-, y agradecer al dios Príapo (fig. 10) su protección sobre la reserva hídrica de la que dependía la supervivencia de la ciudad ${ }^{34}$.

La exégesis priápica ha sido descartada por L. Gasperini, para quien el carácter (iti)fálico de las imágenes no se vincula a la hipertrofia sexual de Príapo sino a la plasmación visual de la especialidad terapéutica de esas aguas y barros, interpretando las figurillas y los bustos como exvotos realizados por fieles curados de sus dolencias gracias a la fangoterapia, quienes habrían expresado su agradecimiento a la deidad sanadora mediante la elaboración y ofrenda de esas imágenes. En su opinión, ésta sería un numen praesens ctónico de origen prerromano, sin relacionarla con ningún teónimo concreto ${ }^{35}$. En la misma línea, L. Curchin interpreta las representaciones fálicas como objetos votivos anatómicos asociados a un culto a la fertilidad desconocido, que continuaría la tradición prerromana de las cuevas-santuario celtibéricas ${ }^{36}$. También defiende el carácter indígena de la(s) deidad(es) del santuario, J. Gómez-Pantoja, quien opta por su identificación como las Matres sobre la base del hallazgo en

33. Vid. n. 13; y Alfayé, loc. cit., 2010, 186-192, con numerosos ejemplos.

34. Palol y Vilella, loc. cit., 1986, 15-25; ID., op. cit., 1987, 129-132, 134, figs. 26-29, por F.J. Navarro y A.M. Poveda, Sexo y erotismo: Roma en Hispania, Murcia 2009, 17.

35. Gasperini, loc. cit., 163-166 y 170, lám. VI-VIII.

36. Curchin, op. cit., 184. Sobre cuevas-santuario celtibéricas, cf. Alfayé, op. cit., 2009, 30-123; EAD., loc. cit., 2010, 177-218; y EAD., "Dinámicas rituales en cuevas y abrigos de la Celtiberia”, en C. Rísquez y C. Rueda (eds.), Santuarios iberos: territorio, ritualidad y memoria, Jaén 2013, 385-395. 
Clunia de siete aras dedicadas a estas diosas (fig. 2) - que en la Hispania Céltica aparecen muy vinculadas al elemento acuático -, y a la supuesta existencia de una correlación entre el área de dispersión de esos altares en la superficie urbana y la ubicación topográfica de la cueva. Según esta propuesta, que asume la coetaneidad de las aras y los letreros rupestres - lo que no deja de resultar cuestionable-, los fieles habrían agradecido públicamente a las Matres su sanación, ocurrida en el subsuelo, en un edificio cultual público situado en la superficie, lo que explicaría la inexistencia de dedicaciones a esas diosas en la propia cueva ${ }^{37}$. Sin embargo, la revisión de los contextos de hallazgo de estas aras muestra que esa supuesta correlación topográfica entre la dispersión de los epígrafes y el santuario subterráneo es problemática. Sabemos que de los siete altares a las Matres publicados como procedentes de Clunia, dos fueron recuperados en el transcurso de excavaciones arqueológicas en los contextos domésticos de la «casa $n^{\circ} 1$ » (figs. 2-3) y la «casa $n^{\circ} 2 »$, como se expuso anteriormente ${ }^{38}$. Otro altar fue descubierto casualmente en el año 1982 en un campo de la zona noroeste de la ciudad, «no lejos de las casas 1 y 2 », donde también se encontró un epígrafe dedicado a I.O.M. ${ }^{39}$. Además, se conoce la existencia de un altar cluniense dedicado a las Matres, que hoy está desaparecido (CIL II 2776 $)^{40}$, y de otro que fue reutilizado como banco en la ermita de Nuestra Señora de Castro $^{41}$, desconociéndose el contexto originario de ambos. En cuanto a las otras dos aras a las Matres incluidas en el corpus epigráfico de Palol y Vilella, éstas formaban parte de una colección privada de Covarrubias (Burgos), por lo que se desconoce su procedencia exacta, no descartando J.M. Abásolo que pudieran provenir tanto de Clunia como del asentamiento romano de Lara de los Infantes (Burgos), o incluso del yacimiento romano de «Castro de las Muelas» existente dentro del término municipal de Covarrubias ${ }^{42}$.

Por tanto, la revisión de las circunstancias del hallazgo de las aras clunienses de las Matres impide afirmar que todas ellas procedan de un mismo espacio cultual público situado sobre la cueva-santuario, que hasta la fecha tampoco habría sido localizado. Sin embargo, somos conscientes de que los contextos originarios de estos altares distan de estar resueltos, $y$ que tres de las aras a las Matres -las encontradas en las «casa n ${ }^{\circ} 1 »$ y «casa no 2 », y la hallada en el campo existente entra ambas-, sí fueron descubiertas en un área del entramado urbano

37. Gómez Pantoja, loc. cit., 421-430.

38. Vid. supra; y Pérez Ruíz, op. cit., 201, 211, 340-341, fig. 222, 369-371, 420, 463-464, tabla 19, nº 44 y 49, BU/Clunia04-I y BU/Clunia09-I.

39. Palol y Vilella, op. cit., 1987, 28, n 13, para el ara a las diosas, y 26, n 10, para el otro altar; y Gómez Pantoja, loc. cit., 432 y 429.

40. CIL II 2776; Palol y Vilella, op. cit., 1987, 162-163, no 211, con la lectura T(itus) Fraternus/ Matribus/ Gallaicis/ v(otum) s(olvit) l(ibens) m(erito).

41. Palol y Vilella, op. cit., 1987, 27, n o 12, la fechan en los siglos I-II d.C. y proponen la lectura Matrib[us]/ Brigeacis/ L(ucisu) Aelius/ Phainus/v(otum) s(olvit) l(ibens) m(erito).

42. Palol y Vilella, op. cit., 1987, 28-29, $\mathrm{n}^{\circ}$ 14-15, con datación en el siglo I d.C. Beltrán y Díaz, loc. cit., 36-37, no 2.5 y 2.4, figs. 10-11, y p. 38, n. 81, las fechan en el II d.C. y ofrecen las lecturas Matribus / Endeiteris/ Felix/ Priscae/v(otum) s(olvit) l(ibens) m(erito), y Matribus/ Abascant/tus Mar/cellae/ex voto. Sobre la procedencia incierta de estas aras, cf. J.A. Abásolo, "Dos aras inéditas del Museo Arqueológico de Burgos", Trabajos de Prehistoria, 31, 1974, 365-370. 
que se localiza topográficamente cerca del santuario subterráneo, y donde también se hallaron -en concreto en la «casa $n^{\circ} 1 »-$ el altar a Neptunus y los dos sillares decorados con falos y tridentes (fig. 6). Pero quizás, como han propuesto F. Beltrán y B. Díaz, esa concentración cultual de dedicaciones a dioses relacionados con las aguas en un área próxima al acuífero pueda deberse al hecho de que las aras fueron ofrecidas por los devotos en sus propias casas, en agradecimiento a las deidades de las que dependía el suministro de agua potable y a las que, además, se confería un poder curativo, a juzgar por la fórmula pro salute atestiguada en las aras. Esa veneración doméstica y local a unas diosas salutíferas explicaría, en su opinión, la diversidad de epítetos que presentan las Matres clunienses ${ }^{43}$. Por ello, aunque la identificación como las Matres de la(s) divinidad(es) que presidía(n) el santuario de la «Cueva de Román» propuesta por Gómez Pantoja resulte sugerente, parece preferible mantener de momento la cautela sobre la identidad de los dioses del subsuelo cluniense, y sobre la existencia de un espacio cultual en superficie dedicado a ellos, a la espera de nuevas investigaciones.

En cuanto al supuesto carácter prerromano o indígena de esa(s) deida(es) defendido por Gasperini, Gómez Pantoja y Curchin, y a la posibilidad planteada por J.M. Abascal de que el santuario existiera «incluso antes de la promoción municipal de época tiberiana» ${ }^{44}$, lo cierto es que no sabemos desde cuándo era conocida la existencia de ese complejo kárstico, ni de ese tramo del mismo en particular, entre las poblaciones del entorno. De hecho, ignoramos si su descubrimiento está directamente vinculado a la fundación romana de la ciudad de Clunia en época julio-claudia, o si la población celtibérica local que habitaba el asentamiento del «Alto del Cuerno» ya conocía esa cavidad y la reserva hídrica que albergaba, y además la frecuentaba con una finalidad religiosa. Con la información actual, resulta imposible determinar desde cuándo la cavidad (o una parte de ella) fue utilizada como un santuario y a qué deidad estaba consagrada, aunque a juzgar por la documentación epigráfica parece que el período álgido de su uso ritual fue la época tiberiana. Tampoco sabemos cuándo concluyó la frecuentación religiosa de la cueva, ya que aunque las inscripciones más tardías se fechan a finales del siglo I y/o comienzos del siglo II d.C., ¿significa eso que a partir de entonces cesaron las visitas religiosas al subsuelo cluniense, aunque la ciudad estuviera habitada hasta época tardoantigua? ¿O que se produjeron variaciones en las formas ceremoniales del culto que comportaron el abandono de la escritura como medio de comunicación con los dioses, pero el santuario siguió siendo frecuentado?

\section{Las dinámicas del culto en la «cueva de Román»}

En cualquier caso, la elección de la «cueva de Román» como un espacio cultual parece estar íntimamente ligada a la existencia de la reserva hídrica y a su mitologización y sacraliza-

43. Beltrán y Díaz, loc. cit., 37-38; hipótesis compartida por Pérez Ruíz, op. cit., 340-341, 369-371, fig. 10.

44. Gasperini, loc. cit., 170; Curchin, op. cit., 184; Gómez Pantoja, loc. cit., 429-430; J.M. Abascal, "La recepción de la cultura epigráfica romana en Hispania”, en L. Abad (Ed.), De Iberia en Hispania. La adaptación de las sociedades ibéricas a los modelos romanos, Alicante 2003, 257-263 (especialmente 259). 
ción, en tanto que ésta posibilitaba la vida y la prosperidad de la ciudad de Clunia y de sus habitantes (fig. 1).

La interpretación de la cavidad como un santuario de sanación mediante el recurso medicinal de la fangoterapia ha llevado a identificar las figurillas y grabados como representaciones de los devotos y de sus partes sanadas, es decir, como objetos votivos anatómicos (fig. 9). Sin duda, la arquitectura natural de la cueva hubo de condicionar la forma de transitar por ese espacio y las dinámicas visuales del culto, así como el itinerario que partiendo desde el centro mismo de la ciudad conducía a los devotos hacia las numinosas profundidades de la tierra, lo cual debía provocar una experiencia psicosomática transformativa que pudo ser tan decisiva en la curación como las supuestas propiedades salutíferas de las aguas y lodos, que aún no han sido analizadas. Al proceso curativo debió contribuir, además, la propia contemplación de la inscripciones y las imágenes ya existentes, narrativas textuales y visuales de experiencias religiosas previas de otros fieles que habían expresado así la milagrosa actuación de la divinidad sobre sus cuerpos y que, por tanto, devenían en parte de la «realidad objetiva» del santuario en tanto que «atestiguaban» una presencia ininterrumpida de la divinidad en ese espacio particular (fig. 5). A cada paso por el subsuelo cluniense, los fieles «comprobaban» la continua y probada eficacia taumatúrgica de la divinidad en ese santuario, dentro de una dinámica visual que generaba una potente experiencia religiosa que los predisponía a sentir, también ellos, la anhelada y benéfica presencia divina ${ }^{45}$.

La inscripción S20 atestigua la presencia en la cavidad de un lutor, Annius Paternus, que Gasperini identifica como el especialista que aplicaba la fangoterapia fría a los peregrinos $^{46}$. Ello podría hacernos pensar en la existencia de un personal religioso especializado que organizaba y supervisaba las actividades cultuales realizadas en el santuario hipogeo, aunque quizás ese epígrafe simplemente deje constancia de que ese individuo se aplicó a sí mismo el lodo. No sabemos si era realmente necesario descender al santuario kárstico para la utilización del barro, o si éste podía ser también aplicado en la superficie, ni si hubo en el subsuelo algún espacio reservado exclusivamente para la práctica de la fangoterapia. ¿Cualquier barro servía, o sólo el que procedía de una determinada zona de la cavidad? ¿Qué gestos y fórmulas rituales acompañaban el embadurnamiento medicinal con lodo? Y, una vez que el fiel se había curado, ¿era necesario que regresara a las profundidades para dejar un exvoto -gráfico o textual- como testimonio de la eficacia curativa de la deidad, o podía cumplir su promesa y dar gracias en un espacio cultual cívico ubicado en la superficie, del que no conocemos nada en absoluto -salvo, de ser acertada la hipótesis de Gómez Pantoja, las aras a las Matres (fig. $2) ? ¿^{\mathrm{O}}$ es posible que la propia realización de las figurillas (fig. 9), grabados e inscripciones (figs. 7-8) fuera una forma ceremonial de propiciar que lo solicitado a la divinidad se cum-

45. Alfayé, op. cit., 2011, 157 ss.

46. Gasperini, loc. cit., 163-164, 167, láms. VI-VIII, con las lecturas Aemilius/ Firmus/ Quirinius/ I[-] I oblitus/ argila (S19), y Anni[us]/ Pater[nus]/ luto/r (S20). Vid, también Palol y Vilella, op. cit., 1987, 134, figs. 30; y H. Gimeno, “¿Qué escribían en la paredes los grafiteros de Hispania?”, Memoria, 5, 2007, 73-80 (especialmente 74-75). Sobre el uso terapéutico de los fangos, cf. F. Maraver, "Antecedentes históricos de la peloterapia”, Anales de hidrología médica, 1, 2006, 17-42. 
pliera y, por tanto, que estemos ante manifestaciones de súplica y no de agradecimiento? ¿Son imágenes anatómicas votivas retrospectivas o prospectivas? ¿Representan órganos enfermos o ya curados, o partes sanas para las que se solicita protección?

Teniendo en cuenta los paralelos documentados en otros santuarios del mundo antiguo, las figurillas de barro y los grabados de testas de la «cueva de Román» podrían ser tanto representaciones pars pro toto de los fieles, como simulacra de la parte enferma del cuerpo del solicitante, que explicitaba así su demanda concreta a la divinidad, transfiriendo además su malestar -migrañas, jaquecas, etc.- a esa imagen (fig. 9). En cuanto a las numerosas imágenes fálicas e itifálicas que proliferan en el santuario -entre las que sugiero incluir el pájaro modelado en barro en tanto que podría tratarse de una metáfora visual del pene, dada la asimilación del falo con aves en la jerga sexual latina y en numerosas imágenes grecoromanas $^{47}$-, resulta indudable que el pene erecto representa metonímicamente la identidad (ultra)masculina, y que está vinculado simbólicamente a la fertilidad, la vida y el bienestar, por lo que poseía además una valencia profiláctica. La presencia de estas imágenes fálicas en éste y en otros santuarios del mundo antiguo ha sido interpretada como una práctica cultual destinada a obtener/agradecer la curación de enfermedades vinculadas con los genitales masculinos -fimosis, problemas de disfunción eréctil e impotencia, priapismo, problemas del tracto urinario como piedras o hernias, enfermedades de transmisión sexual, etc. -, o también como una forma ritual de prevenir esos problemas. Pero estas representaciones anatómicas podrían responder, igualmente, a la petición -tanto por parte de hombres como de mujeres- de fertilidad individual o de bienestar para toda la comunidad, o ser también una forma de expresar el agradecimiento por el don personal/colectivo de la fecundidad recibido. En cualquier caso, y ya se trate de cabezas (fig. 9), máscaras o falos, estaríamos ante personificaciones votivas de los oferentes, cuya realización habría formado parte de las prácticas cultuales normativas celebradas en la cueva cluniense $e^{48}$.

47. Sobre la asociación del ave con el pene en el mundo clásico, cf., por ejemplo, J. Boardman, "The phallusbird in Archaic and Classical Greek Art”, Revue Archéologique, 2, 1992, 227-243; Johns, loc. cit., 53-53 y 6871, lám. 13; Veyrac, loc. cit., 291-292, figs. 5-7, 14-15; J.N. Adams, The latin sexual vocabulary, Gloucester 1982, 29, 31-33, 53, n. 47; J. Méndez, "Han tal bec vostres gallines? Sobre la representación medieval del falo a través de algunos ejemplos iconográficos y literarios pertenecientes a la narrativa catalana del siglo XV”, Miscelánea medieval murciana, 33, 2009, 123-142 (especialmente 124-132, figs. 1-8).

48. Sobre testas y falos como objetos votivos anatómicos en el mundo antiguo, vid., entre otros, S.P. Girardon, Italic votive terracottas from the British Museum: a stylistic appraisal in their religious and historical settings, London 1994, 75-78; L. Meskell, Object Worlds in Ancient Egypt, Oxford-New York 2004, 141142; A.L. Blomerus, The anatomical votive terracotta phenomena: healing sanctuaries the Etruscan-latialcampanian region during the fourth trough first centuries, Cincinnati 2005, 113-114, 118-125; J. Hughes, "Fragmentation as metaphor in the Classical healing sanctuary", Social History of Medicine, 21, 2, $2008,217-$ 236; K. D'Arcy Dicus, Actors and agents in ritual behaviour: the sanctuary of Grasceta dei Cavallari as a casestudy of the E-L-C votive tradition in Republican Italy, Michigan 2012, 148-153; E. Colantoni, "Male/female in the Roman world", ThesCRA, VIII, The J. Paul Getty Museum, Los Angeles 2012, 271-282 (especialmente 278). Sobre enfermedades sexuales masculinas en la Antigüedad, cf. J.N. Corvisier, "Stérilités, impuissances 
Por otra parte, Gasperini considera que la fangoterapia practicada en el santuario no sólo se limitaría a los órganos sexuales (S19-20), sino que también otras partes enfermas como los ojos (S8, S15) y los pies (S33) serían cubiertos con barro como parte del ritual curativo celebrado allíi ${ }^{49}$, aunque lo cierto es que no se han documentado representaciones de dichos órganos. Por ello, y en relación a S33, ped[---], quizás no deba descartarse que se trate de una alusión epigráfica a una pedicatio, un tipo de inscripción erótica documentada en otros contextos rupestres sagrados del mundo antiguo ${ }^{50}$, pero que no deja de resultar inesperada en el marco de un supuesto santuario de sanación. Es posible, además, que éste no sea el único letrero de contenido sexual de la cueva cluniense si se acepta la lectura que ofrecen Palol y Vilella del epígrafe S17, cusprispriscus/venit, como «un quialismo vocálico y una tilogía que evidenciaría la lascivia de su autor» ${ }^{51}$.

Desde una perspectiva no excluyente sino confluyente, cabe también plantear otra posible interpretación de esas imágenes fálicas del subsuelo cluniense: que su elaboración y ofrenda estuvieran destinadas a propiciar la (re)producción del agua subterránea de la que dependía la vida de la ciudad. Sabemos que los romanos pensaban que los espacios rupestres estaban "animados», y que la piedra y los metales extraídos de minas y canteras podían regenerarse. Por ello R. Halleaux y T. Derks han interpretado los grabados de falos en sus paredes rocosas -concebidas como membranas de conexión con el ámbito sobrenatural- como representaciones que podían contribuir performativamente a la rápida fecundación y reproducción de la tierra y de sus frutos (aspera viscerae terrae) ${ }^{52}$, y quizás

et maladies sexueles masculines dans le Monde Antique", en J.N. Corviser, C. Didier y M. Valdher (Eds.), Thérapies, Médecine et Démographie Antiques, Amiens 2001, 237-256.

49. Gasperini, loc. cit., 166, lám. XI.

50. Así, por ejemplo, sobre la superficie rocosa del Monte Bego, en el Valle delle Meraviglie (Italia), dos individuos dejaron constancia epigráfica de sus proezas sodomitas entre los siglos I a.C. y I d.C. en un paraje considerado sagrado por la población local, aunque quizás en esa época fuera ya utilizado como un área de trashumancia. Sobre estas inscripciones cf. J. Gascou, "L' inscription romaine de la paroi B de la Vallée des Merveilles", en H. Lumley et al., Vallée des Merveilles, Nice 1976, 127-128, fig. 66; N. Lamboglia, "Le incisioni di etá romana in Val Meraviglie", Studi Genuensi, 1982, 25-27, las relaciona con un ambiente pastoril trashumante; G. Menella, "Le iscrizioni rupestre della Valle delle Meraviglie e della Valle dell' Ossola", en L. Gasperini (Ed.), Rupes Loquentes, Istituto Italiano per la Storia Antica, Roma 1992, 14-21 (especialmente 20), quien vincula los epígrafes con un destacamento militar estacionado en esa zona.

51. Palol y Vilella, loc. cit., 1986, 21; EAD., op. cit., 1987, 132 y 134; cf. también HEp 1, 1989, 143f; y HEp 2, 1990, 183f, con la lectura Cuspius Priscus venit.

52. R. Halleux, "Fecondité des mines et sexualité des pierres dans l'Antiquité greco-romaine", Revue Belge de Philologie et d' Histoire, 18, 1, 1970, 16-25; T. Derks, Gods, temples, and ritual practices. The transformation of religious ideas and values in Roman Gaul, Amsterdam 1998, 77 y 143; N. Boivin, "From Veneration to Exploitation: Human Engagement with the Mineral World", en N. Boivin y M.A. Owoc (Eds.), Soils, Stones and Symbols: Cultural perceptions of the Mineral World, London 2004, 1-29; S. Alfayé y F. Marco, "Santuarios en canteras y romanización religiosa en Galia e Hispania", en J. Mangas y M.A. Novillo (Eds.), Santuarios suburbanos y del territorio en las ciudades romanas, Madrid 2014, 53-86 (especialmente 78-81). Sobre falos grabados en canteras, como las de Saint-Boil, Maastricht, Königswinter, Kruft ó Tiber, vid., entre otros, Derks, op. cit., 77, n. 29-30; D. Lukas, "Carrières et extraction romaines dans le Nord-Est de la Gaule et en 
en Clunia sucediera lo mismo con el agua. Considero posible, por tanto, que la cueva de Román fuera concebida como un gran útero, un espacio creador donde se producía y se recolectaba el agua para su consumo por los habitantes de la ciudad, y que mediante la realización de esas imágenes fálicas se persiguiera fecundar a la tierra y facilitar ritualmente su tarea (re)generadora, y evitar así que las reservas hídricas se agotaran, sirviendo ese ritual tanto para agradecer a la divinidad del subsuelo los bienes recibidos como para propiciar la permanente creación de éstos ${ }^{53}$.

En cuanto a la sociología devocional de la cueva-santuario cluniense, el registro epigráfico muestra que estaba compuesta mayoritariamente por hombres pertenecientes a grupos sociales muy variados, documentándose tanto esclavos - Hermes Aionis (S8, S12), Astyan[ax?] (S5), Soteles (S37) - como magistrados locales -Fabricius, quattuorvir (S1), el edil Bergius Seranus (S2-S4) (fig. 7), los quattuorviri (S13) (fig. 8) -, cuyas motivaciones para adentrarse en el inframundo se analizarán más adelante. Solo dos mujeres, Glauca (S22, S24, S39) y Secundia (S23), grabaron sus nombres en la cavidad. Para H. Gallego serían esclavas o indígenas de condición modesta y sin derecho de ciudadanía, cuya presencia, según Gasperini, estaría motivada por el deseo de encontrar curación para sus genitales enfermos y/o sus problemas de infertilidad ${ }^{54}$. Además de los mencionados Bergius Seranus (S2-S4, fig. 7) y Glauca (S22, S24, S39), se documentan otros casos de iteración antroponímica-Hermes (S9, S12, S31) y Priscus (S16-18, S28)- que podrían responder al hecho de que esos individuos (u otros del mismo nombre) hubieran descendido varias veces a la cavidad, o a que hubieran realizado varias inscripciones durante una única visita, una disyuntiva que se plantea también en otros graffiti realizados en diversos santuarios del Imperio Romano, en los que se constata igualmente esa insistencia en la memorialización de la propia presencia a través de la reiterada escritura autógrafa, así como la interacción entre letrero e imagen, el «principio de imitación» del grafismo, y una innegable vocación de audiencia ${ }^{55}$.

Rhénanie", Gallia, 59, 2002, 155-174 (especialmente 159); G. Monthel, "Le carrière gallo-romaine de SaintBoil (Saône-et-Loire) ", Gallia, 59, 2002, 89-118 (especialmente 106-114); Alfayé y Marco, loc. cit., 2014, 76-77 y 79 , fig. 5.

53. Sobre la cueva como útero cósmico, cf. M. Rappenglück, "Cave and cosmos, a geotopic model of the world in ancient cultures", en M.P. Zelda y J.A. Belmonte (Eds.), Lights and shadows in Cultural astronomy, Dolianova 2007, 241-249 (especialmente 241-243).

54. Palol y Vilella, op. cit., 1987, 134-135; H. Gallego, "La mujer en las estructuras religiosas de la Hispania septentrional. Consideraciones en base a la epigrafía votiva hispano-romana en el territorio castellano leonés", Ilu. Revista de historia de las religiones, 9, 2004, $69-89$ (especialmente 81, n. 55, 84, 88, cuadro I); y Gasperini, loc.cit., 166. La atribución de la realización autógrafa de esas inscripciones a dos mujeres de condición servil o de origen social modesto, implica asumir que ambas poseían un cierto nivel de alfabetización.

55. Vid. n. 13. Además es posible que, como plantea P. Hameau, "Des espaces bons pour l'exclusion", en G. Dimitriadis (Ed.), Landscape in mind: dialogue on space between Anthropology and Archaeology, Oxford 2009, 121-124, la escritura hubiera tenido una función catártica y permitiera afirmar la propia identidad y presencia en un espacio en situaciones difíciles de liminalidad y de disjonction identitaire, unas características que se adecúan bien a la topografía subterránea cluniense. 
Podemos preguntarnos, además, qué otro tipo de prácticas religiosas se realizaron en la cueva, cómo se organizaba el culto y a qué responde la presencia de magistrados clunienses en el santuario kárstico (figs. 7-8), documentada en las inscripciones S1, Fabricius / IIIIvir / hic / [fuit?]; S2, Bergius Seranus / aedilis dicit / quisquis hoc venerit /+++; S3, Bergius / Seranus/ hic fuit / [aedi]lis; S4: Ber(gius) Seranus / aed[ilis]; y S13, IIII/viri/ vene/runt ${ }^{56}$. Sobre la base de la documentación actual resulta difícil ofrecer respuestas a estos y otros interrogantes, pero es posible que existiera un procedimiento ritual normativo si, como sugieren Gasperini y Gómez Pantoja, el epígrafe S2 es un decreto o lex sacra que regulaba el acceso y el funcionamiento del santuario ${ }^{57}$ (fig. 7). Así, se ha planteado que la función de los magistrados locales documentados en el subsuelo fuera la de acompañar y vigilar a los fieles en su peregrinaje en fechas regladas, para evitar la contaminación de las aguas de las que se abastecía toda la ciudad. Otra hipótesis es que tanto el edil Bergius Seranus (fig. 7) como el quattuorvir Fabricius accedieran a la cueva por motivos personales con el fin de encontrar cura a sus dolencias, lo que no explicaría la inscripción colectiva S13, IIII/viri/ vene/runt (fig. 8). Para Gasperini, los magistrados clunienses habrían descendido al santuario como parte de sus obligaciones públicas, que incluían el control periódico del estado de salubridad de la reserva hídrica y la inspección del buen funcionamiento de las infraestructuras hidráulicas, y quizás también la supervisión de los devotos, que sólo habrían accedido al santuario bajo vigilancia y en fechas concretas. Una interpretación similar es la de E. Melchor Gil, E. Sánchez, y A.D. Pérez Zurita, para quienes los magistrados bajaban al santuario como parte de sus competencias edilicias de control de las aguas, interpretando este último la inscripción S13 -que lee como IIII/viri/vene/ verunt-como el testimonio del visto bueno dado por los quattuorviri a una acción realizada en el subsuelo, una lectura que es incorrecta dada la fotografía publicada de este epígrafe ${ }^{58}$ (fig. 8).

En realidad, Palol y Vilella fueron los primeros en relacionar la presencia epigráfica de los magistrados municipales en la cueva con inspecciones relacionadas con el abastecimiento hídrico, pero también con acciones rituales continuadas en el tiempo «a favor de lo que el agua pueda representar para el progreso de la urbs y evidentemente relacionada con

56. Palol y Vilella, op. cit., 1987, 131-133, S1-S4 y S13, figs. 14-18, 24; Gasperini, loc. cit., 163, lám. I-II y V, fig., 24.

57. Gasperini, loc. cit., 163 y 167; Gómez Pantoja, loc. cit., 429.

58. E. Melchor Gil, "Quattuorviri y aediles en los municipios de constitución cuatorviral a finales de la República y época altoimperial”, RSA 43, 2013, 133-152 (especialmente 146); E. Sánchez, "La cura urbis edilicia según la legislación municipal hispana: lex irnitana, capítulo XIX”, Revista internacional de Derecho romano, 11, 2013, 436-467 (especialmente 463-465); A.D. Pérez, "Reflexiones en torno al cuatorvirato en la Hispania romana”, Polis, 16, 2004, 133-168 (especialmente 148 y 156). La lectura IIII/viri/ vene/runt es defendida por Palol y Vilella, op. cit., 1987, 133, fig. 24; HEp 1, 1989, 49, nº 143d; HEp 2, 1990, 60, n 183b; Gasperini, loc. cit., 163, lam. V; y J. Santos y A. L. Hoces de la Guardia, "Fragmento de placa con letras [---] VIR[---] procedente de Termes (Montejo de Tiermes, Soria). ¿Antropónimo, magistratura o indicación de tribu?", Veleia 24-25, 2007-2008, $1081-1087$ (especialmente 1085, n. 14). Sobre las prerrogativas de los magistrados hispanos, cf. E. Ortíz de Urbina (Ed.), Magistrados locales de Hispania. Aspectos históricos, jurídicos y lingüísticos, Vitoria-Gasteiz 2013. 
cualquier fruto fertilizante o propiciatorio de la abundancia ${ }^{59}$. Siguiendo esta propuesta, y teniendo en cuenta el contexto sacro en el que se producen esas visitas, considero posible que, como parte de las obligaciones de su cargo, de su provincia, los magistrados bajaran a la «cueva de Román» tanto para supervisar el estado de la reserva hídrica como para realizar prácticas cultuales de agradecimiento y propiciación del poder vivificador de esas aguas en beneficio de la comunidad cívica, de las que pudo formar parte la propia escritura entendida como un acto de culto. Y, en este sentido, cabe recordar la existencia de otras inscripciones votivas realizadas por magistrados locales y/o delegados religiosos en diversos santuarios rupestres romanos.

\section{Actividades cultuales colegiadas en otros contextos rupestres}

Un ejemplo hispano lo ofrecen las casi treinta inscripciones latinas grabadas o pintadas en la pared exterior del abrigo conocido como Sala dels Jurats o Esglesia, en Cales Coves, Alayor (Menorca), que atestiguan la peregrinación anual de aediles o aeditui ${ }^{60}$ a ese lugar cada 21 de abril -XI kalendas maias hoc venimus- entre los años 150 y 214/230 d.C. Esta práctica religiosa de carácter oficial estaba posiblemente relacionada con la celebración institucionalizada del dies natalis de Roma y los Palilia, que comportaba no sólo la peregrinación a esa cueva -cuyo interior fue utilizado como santuario desde el siglo III a.C. hasta finales del I d.C.-, sino también la realización colegiada de la propia inscripción, entre otras actividades cultuales documentadas en ese lugar en los siglos II-III d.C. ${ }^{61}$.

En la cueva-santuario de «La Griega», Pedraza (Segovia), las más de cien inscripciones latinas realizadas en las paredes y en el barro durante los siglos I-IV d.C. atestiguan el culto a Nemedus Augustus Aiuncus, Deva, y quizás también a otros dioses, aunque no sabemos si la utilización religiosa de la cavidad en época romana continúa una tradición

59. Palol y Vilella, op. cit., 1987, 132.

60. Hasta la fecha, la restitución aed(itui) planteada por los editores sería el único caso documentado en la epigrafía hispana de este tipo de personal religioso adscrito a un espacio cultual, cuya abreviatura habitual es aedit(ui). Por ello, y aunque no sea imposible la lectura aed(itui), parece preferible aed(iles) dado que es una abreviatura habitual y está ampliamente atestiguada tanto en Hispania como en el resto del Imperio Romano.

61. CIL II 3718-3724=5992-6000; G. Veny, Corpus de las inscripciones baleáricas hasta la dominación árabe, Madrid 1965, 160-170, no 135-156, figs. 91-96, mapa II; R. Zucca, Insulae Baliares. Le isole Baleari sotto il dominio romano, Roma 1998, 158, 201, 216; Abascal, loc. cit., 259; F. Marco, "Las inscripciones religiosas del ámbito rural como expresión del hábito epigráfico", en VVAA, Espacios, usos y formas de la epigrafía hispana en épocas antiguas y tardoantiguas. Homenaje al Dr. A. Stylow, Mérida 2009, 197-210 (especialmente 201-202, fig. 6); M. Orfila, G. Baratta y M. Mayer, "Los santuarios de Cales Coves (Alaior, Menorca): Coberxo Blanc y Cova del Jurats o de l' Eglesia. Informe preliminar”, CPAG, 20, 2010, 395-433 (especialmente 417-422, fig. 14, láms. III-VII); y "El santuario de Cales Coves (Alaior, Menorca). La cova dels Jurats o Església”, en VVAA, IV Jornades d'Arqueologia de les Illes Balears, Mallorca 2013, 109-117; J.J. Castelló, "La celebración del Natalis Vrbis en Cales Coves (Menorca): ritual y oficiantes", en Homo religiosus. Mediadores con lo divino en el mundo mediterráneo antiguo, e. p. 
cultual celtibérica que habría quedado fosilizada en el carácter indígena de los teónimos ${ }^{62}$. Algunos de los letreros documentan la realización de prácticas rituales colegiadas, y aunque ninguna de estas parejas explicita si ostentaba algún cargo oficial -como sucede en Cales Coves (aediles/aeditui) o en Clunia (aedilis, quattuorviri)-, M. Mayer y J.A. Abásolo los identifican como legati, sacerdotes, magistrados o delegados religiosos que estarían cumpliendo algún encargo cultual colectivo de las comunidades del entorno, para las que la cueva actuaría como un santuario regional ${ }^{63}$. Aunque a diferencia de la reiteración de fechas que se detecta en Cales Coves, que permite identificar una festividad periódica relacionada con un calendario religioso oficial, las referencias temporales de "La Griega» no muestran ninguna coincidencia entre sí, por lo que parecen datar visitas ocasionales ${ }^{64}$. Lamentablemente, tampoco podemos determinar la procedencia de esas parejas ni establecer cuál era el «territorio de gracia» de esta cueva-santuario debido a que en ninguna de las inscripciones se indica la origo de sus artífices. Abásolo ha señalado acertadamente la ausencia de un núcleo de entidad urbana en el entorno de «La Griega» que justificara ese elevado número de inscripciones, ya que en la cercana Pedraza apenas se han encontrado restos romanos. Ello le lleva a identificar esta cueva como un santuario supralocal al que acudirían en peregrinación diversas comunidades situadas dentro de un área de captación cuyo radio no podemos precisar pero que, a juzgar por otros paralelos conocidos, podría oscilar entre seis y treinta km., interpretación que comparto ${ }^{65}$.

El fenómeno de dedicación votiva por parejas se documenta igualmente en otros santuarios rupestres de Hispania. Así, los tituli picti $\mathrm{n}^{\circ} 1$ y $\mathrm{n}^{\circ} 14$ realizados a finales del siglo I

62. S. Corchón (Ed.), La Cueva de La Griega de Pedraza (Segovia), Zamora 1997; F. Marco, "Nemedus Augustus", en VVAA, Aurea Saecula. Studia Palaeohispanica et Indogermanica J. Untermann ab amicis hispanicis oblata, Barcelona 1993, 165-178; M. Mayer y J.A. Abásolo, "Inscripciones latinas", en S. Corchón (Ed.), op. cit., 183-259, figs. 21, 200-254; y EAD. "Restos cultuales romanos en la Cueva de La Griega (Pedraza, Segovia)", Sintria, 3-4, 1995-2007, 347-362; HEp 7, 1997, 246-265, nº 659-763; AE 1997, 303-307, $\mathrm{n}^{\circ}$ 883-907; J.A. Abásolo, "Indígenas e hispanorromanos en la Meseta Norte. Recientes descubrimientos de inscripciones hipogeas", en V.V.A.A., Complutum. Roma en el interior de la Península Ibérica, Alcalá de Henares 1998, 29-37; J. Santos, A.L. Hoces y J. Del Hoyo, Epigrafía romana de Segovia y su provincia, Segovia 2005, 249-284; Alfayé, loc. cit., 2010, 197-206; EAD., op. cit., 2011, 162-164, 190-193; y "Relecturas de algunas inscripciones latinas de la cueva-santuario de "La Griega", Pedraza (Segovia)", Veleia, 31, 2014, 279-287. Quisiera agradecer a la Prof. M. Soledad Corchón la oportunidad de formar parte de su equipo de investigación de la cueva de «La Griega», y haber podido así adentrarme en la cavidad y estudiar directamente las inscripciones latinas, cuya revisión estoy llevando a cabo.

63. Las inscripciones de "La Griega» que han sido relacionadas con prácticas cultuales colegiadas son las siguientes (de acuerdo con la editio princeps de Mayer y Abásolo, loc. cit., 183-259): n 35, Gallus (sestertios) $D\left(\right.$ ?) Q(uintus) Seranus lene res forn[ix]/ Doiderus Silvanvs G(ai) Canini (filius) et [+++] Gallus y Seranus; $\mathrm{n}^{\circ}$ 37, VOTA HIC II, con el desarrollo vota hic (iterum/bis?) o vota hic II (duo) (fecerunt); no 46, Gallus et Fes[t] us; $\mathrm{n}^{\circ} 48$, [---]II VOVIMVS HOC, ya se lea como (iterum/bis) vovimus hoc o como II (duo) vovimus hoc; y no 56 Rubenus [et] Ter(entius) ven(erunt). Cf. también Alfayé, loc. cit., 2010, 199-200; y 2014, 281, III, fig. 3.

64. Mayer y Abásolo, loc. cit., 236-237, 244, 255, nº 70-71, 84, figs. 249-250.

65. Ábasolo, loc. cit., 32; Alfayé, loc. cit., 2010, 202 y ss.

Revista de Historiografía 25, 2016, pp. 355-383. 
d.C. en la pared del abrigo de "Cueva Negra», en Fortuna (Murcia), atestiguan que sendas parejas de dedicantes colocaron estatuillas (xoanon) en ese espacio como parte de su actividad cultual colegiada ${ }^{66}$. En el titulus $\mathrm{n}^{0} 1$ se explicita que la acción ritual tuvo lugar el 27 de marzo, fecha que aparece repetida en otras cuatro inscripciones de la cueva, por lo que es posible que se trate del día en que se celebraba la peregrinación a ese antrum ${ }^{67}$. El otro letrero es el no 14 (II/4), realizado por L. Oculatius Rusticus y Annius Crescens, quienes han sido identificados por A. Stylow y M. Mayer como legati de la ciudad de Ebusus que habrían peregrinado a "Cueva Negra» en misión oficial para asistir a una festividad religiosa celebrada en el santuario y vinculada con la lavatio de Cibeles, realizando estos rituales en nombre de la comunidad ibicenca $^{68}$. I. Velázquez, A. Espigares y A. González Blanco han planteado otras alternativas a «la trama ebusitana y de la Magna Mater», interpretando este epígrafe como el testimonio de una peregrinación de carácter privado celebrada en la festividad del 1 de abril, una fecha consagrada a la diosa Fortuna Balnearis, a quien se rendía culto en el cercano balneario romano de Fortuna. Éste era un santuario salutífero construido en torno a un manantial termal que conformaba, junto con el abrigo de «Cueva Negra», un importante complejo sagrado al que peregrinaban los fieles con el propósito de encontrar cura a sus dolencias, y cuya área de captación incluía a la ciudad de Carthago Nova ${ }^{69}$.

Otro testimonio autógrafo de prácticas cultuales colegiadas en contextos sacrales rupestres de Hispania lo ofrece la inscripción lusitana de Lamas de Moledo, Viseu (Portugal), aunque la interpretación de la identidad de los dedicantes, Rufinus y Tirus, resulte controvertida ${ }^{70}$.

Fuera del territorio peninsular también conocemos otros ejemplos de prácticas votivas por parejas o magistrados realizadas en contextos sagrados rupestres, como, por ejemplo, los casi ochenta letreros dedicados al dios Bacax Augustus grabados en las paredes de entrada a

66. Sobre Cueva Negra, vid. A. González Blanco, M. Mayer y A.U. Stylow (Eds.), La Cueva Negra de Fortuna (Murcia) y sus tituli picti. Un santuario de época romana, Antigüedad y Cristianismo, 4, Murcia 1987; A. González Blanco et alii (Eds.), El balneario romano y la Cueva Negra de Fortuna (Murcia), Antigüedad y Cristianismo, 13, Murcia 1996; A. González Blanco (Ed.), La cultura latina en Cueva Negra, Antigüedad y Cristianismo, 20, Murcia 2003.

67. M. Mayer et alii, "La Cueva Negra de Fortuna (Murcia). Tituli picti”, en González Blanco et alii (Eds.), op. cit., 1996, 407-423 (especialmente 410); A. González Blanco, "Los textos de la Cueva Negra y sus perspectivas histórico-religiosas”, en González Blanco et alii (Eds.), op. cit., 1996, 477-520 (especialmente 489-490, 501, 510).

68. A. U. Stylow y M. Mayer, "Los tituli de la Cueva Negra. Lectura y comentarios literario y paleográfico", en González Blanco et alii (Eds.), op. cit., 1996, 367-406 (especialmente 374-379 y 398); S. Montero, "Integración y mezcla de cultos en el SE de la Península Ibérica: la Cueva Negra (Fortuna, Murcia)", en Integrazione, mezcolanza, rifiuto, Roma 2001, 179-183 (especialmente 174-178); Marco, loc. cit., 201.

69. I. Velázquez y A. Espigares, “Traducción al castellano de los textos de la Cueva Negra”, en González Blanco et alii (Eds.), op. cit., 1996, 453-476 (especialmente 463-466); González Blanco, op. cit., 1996, 488490, 501, 510; G. Matilla, A. Egea y J. Gallardo, "La sacralidad de las aguas. El caso de los santuarios romanos de Fortuna (Murcia)”, en I. Rodá (Ed.), Aqua Romana. Técnica humana y fuerza divina, Madrid 2005, 162176.

70. Alfayé y Marco, loc. cit., 290-292 y 296-301. 
la cueva de Mons Taya, Chettaba (Argelia), por parejas de hombres, en su mayoría magistri del asentamiento romano de Thibilis situado a unos $18 \mathrm{~km}$. Entre los años 210 y 274 d.C., éstos peregrinaron anualmente a la cueva para cumplir con obligaciones religiosas comunitarias, dejando constancia epigráfica de sus nombres y de la fecha de sus visitas -calendas de marzo, abril o mayo-, quizás relacionadas con una festividad local de primavera. Se desconoce si la frecuentación religiosa de ese lugar hunde sus raíces en una tradición indígena, pero sabemos que la peregrinación colegiada deja de estar atestiguada epigráficamente a finales del siglo III d.C., hecho que R. Cid relaciona con un cambio en el estatuto jurídico de Thibilis que habría supuesto una reorganización del panteón oficial y del culto cívico. Un fenómeno similar se observa en el abrigo de Crypta Zemma, también en Argelia, hasta donde peregrinaron magistrados de la Respublica Phuensium a lo largo del siglo II d.C. para rendir culto a una divinidad local mencionada en las inscripciones pintadas o grabadas sobre la roca como G.D.A. (¿G(iddabae) $D(e o) A($ ugusto)?), quien podría ser el dios tutelar de esa comunidad y de su territorio, y cuyo culto habría estado vinculado a circunstancias socio-políticas similares a las de Bacax Augustus ${ }^{71}$.

$\mathrm{Al}$ igual que sucede en el caso cluniense, todos estos espacios rupestres de culto plantean interrogantes difíciles de responder con la información disponible: cronología de su uso como santuario, regulación del acceso, transformaciones a lo largo del tiempo, alcance de su territorio de gracia, dinámicas rituales celebradas en ellos, personal religioso asociado, etc.

\section{Otras prácticas religiosas en el subsuelo cluniense}

Diversos investigadores han vinculado el santuario de la «cueva de Román» con prácticas oraculares ¿celtibérico-romanas? ${ }^{72}$ sobre la base de un texto de Suetonio, Galba 9, 2, en relación a los acontecimientos ligados a la proclamación imperial de Galba en el 68 d.C. En él se alude a la existencia en Clunia del registro escrito de un omen imperii que había sido emitido ¿en lengua vernácula o en latín? por una puella fatidica doscientos años atrás, y que el sacerdote del templo de Júpiter habría recuperado en ese conveniente momento tras un sueño revelador:

71. CIL VIII 6267-6302 = 19249-19281; J. Alquier y P. Alquier, Le Chettaba et les grottes à inscriptions latines du Chettaba et du Taya, Constantine 1929, 141-188; J. Toutain, Les cultes païens dans l' Empire romain. III, Roma 1967, 42, 45, 47-50, 59-61, 115, 117-118; S. Gell y H.G. Pflaum, Inscriptions latines de l'Algerie. Tome Deuxième, Argel 1976, 407-421, n 4502-4585; R. Cid, “Oligarquías urbanas y cultos indígenas en el Noroeste de África. El ejemplo de las inscripciones de Bacax Augustus”, Memorias de Historia Antigua, 8, 1987, 133-151.

72. Gómez Pantoja, loc. cit., 427; Mierse, op. cit., 184-185 y 196-197, ya había relacionado «the apse at the rear» de la cella del templo de Júpiter con el sitio del oráculo. Sobre la relación de Galba con Clunia, cf. E.W. Haley, "Clunia, Galba and the events of 68-69”, ZPE, 91, 1992, 159-164. Sobre las cuevas como espacios oraculares en el mundo antiguo, vid., por ejemplo, Y. Ustinova, Caves and the Ancient Greek Mind. Descending Underground in the Search for Ultimate Truth, Oxford 2009, 53-155. 
Nec diu cunctatus, condicionem partim metu, partim spe recepit; nam et mandata Neronis de nece sua ad procuratores clam missa deprenderat, et confirmabatur cum secundissimis auspiciis et omnibus virginis honestae vaticinatione, tanto magis quod eadem illa carmina sacerdos Iovi Cluniae ex penetrali somnio monitus eruerat ante ducentos annos similiter a fatídica puella pronuntiata. Quorum carminum sententia erat, oriturum quandoque ex Hispania principem dominumque rerum.

S. Crespo Órtiz de Zárate relaciona esta profecía con una adivina indígena que habría vaticinado a Escipión la caída de Numancia en el 133 a.C., mientras que G. Fontana, de ser cierta la noticia de Suetonio, prefiere ponerla en boca de una adivina itálica que acompañaría a las tropas romanas ${ }^{73}$. Pero según Suet., Galb. 8, éste no sería el único omen imperii hispano de connotaciones religiosas relacionado con el futuro emperador ${ }^{74}$, sino que se habrían producido también otros, lo que permite pensar que incluso aunque hubiera existido realmente ese texto oracular cluniense, su oportuno «descubrimiento» pudo responder más bien a una inteligente campaña propagandística del general. Para legitimarse ideológicamente, Galba no habría tenido reparos en re-inventar/fabricar la tradición de una antiquísima profecía de poder «casualmente» vinculada a la ciudad de Clunia, un episodio que recuerda, en cierta forma, a la premeditada falsificación de carmina que anunciaban la epifanía del dios Glykon realizada por el embaucador Alejandro en la obra de Luciano El falso profeta ${ }^{75}$. Por ello, considero que de este texto no puede inferirse el carácter oracular de la cavidad de Clunia, aunque el relato de Suetonio sí muestra la íntima relación entre religión y poder en la sede del conventus Cluniensis, y evidencia que, como bien expresó Tácito, Hist. 1, 4, 2, el centro del poder romano se había desplazado ya de la Urbe a las provincias en tanto que «podía hacerse un príncipe en cualquier lugar distinto de Roma».

\section{Reflexiones finales}

Sin duda, la elección de la «Cueva de Román» como espacio cultual estuvo ligada inseparablemente a la sacralización de la reserva de agua que permitía la prosperidad de la comunidad ciudadana cluniense (fig. 1), aunque las prácticas cultuales celebradas en ese santuario parecen responder a motivaciones heterogéneas, se expresan a través de formas ceremoniales

73. Sobre esta profecía, vid. S. Crespo Ortiz de Zárate, "Sacerdotes y sacerdocio en las religiones indoeuropeas de Hispania prerromana y romana”, Ilu, 2, 1997, 17-37 (especialmente 35); T.W. Hillard, "Scipio Aemilianus and a prophecy from Clunia", Historia, 54, 3, 2005, 344-348; y G. Fontana, "Aprendices de magos: niños, magia y adivinación en época imperial romana”, en D. Justel (Ed.), Niños en la Antigüedad. Estudios sobre la infancia en el Mediterráneo Antiguo, Zaragoza 2012, 236-262 (especialmente 253-259).

74. Vid. Alfayé, op. cit., 2009, 336-338; y, en general, M. Requena, El emperador predestinado. Los presagios de poder en época imperial romana, Madrid 2001.

75. Sobre este texto, vid. S. Alfayé, "Fraudes sobrenaturales: embaucadores, crédulos y potencias divinas en la antigua Roma”, en F. Marco, F. Pina y J. Remesal (Eds.), Fraude, mentiras y engaño en el mundo antiguo, Barcelona 2014, 65-95. 
diversas, y fueron realizadas por agentes rituales de sociología variada. Desde ritos cívicos vinculados al abastecimiento, mantenimiento y regeneración del agua fósil, hasta rituales de propiciación de la fertilidad individual y colectiva; rituales de sanación de los órganos sexuales mediante peloterapia; realización de figurillas (fig. 9), imágenes y textos entendida como una operación cultual (figs. 7-8); quizás ingesta de agua procedente de ciertas zonas del santuario, con la que podría vincularse el vaso modelado en barro sobre el que se grabó la inscripción S15 ${ }^{76}$; e incluso el depósito de objetos en contexto acuático, entre otras. En cualquier caso, solo la actualización de la información publicada hasta la fecha sobre este espacio subterráneo, y el desarrollo de nuevas campañas arqueológicas, permitirán avanzar en la comprensión del mismo y desentrañar las motivaciones de los diferentes agentes rituales documentados, las relaciones existentes entre individuos de tan variada condición social, la articulación de los diversos usos de la cueva, y el significado y propósito de las representaciones figuradas y las actividades rituales allí atestiguadas.

Sin embargo, aunque todo intento explicativo de la "Cueva de Román» resulte por el momento especulativo, tanto las prácticas cultuales realizadas en ese espacio como otras cívicas y domésticas documentadas en diversos ámbitos de la sede conventual cluniense a las que se aludió anteriormente, muestran la complejidad, dinamismo y variedad del fenómeno religioso en una de las ciudades del poder de la Hispania Céltica, así como los problemas documentales y metodológicos que plantea su estudio, y las posibilidades de una línea de investigación en absoluto conclusa.

76. Palol y Vilella, op. cit., 1987, 133, figs. 3-4 y 25. 